\title{
A Review on Potential of Biomass based Bioenergy in Pakistan based on Present case and Future Perspectives
}

\begin{abstract}
Future energy security and environmental issues are major driving forces for increased biomass utilization globally and especially in developing countries like Pakistan. For efficient utilization of indigenous biomass resources in the future energy mix, it is important to gain knowledge of current energy system in various sectors. Some of the technologies and initiatives are under development to achieve transition from non-renewable resources to renewable resources, and reducing fossil fuel dependency and greenhouse gas emissions. Recently, number of proposals has been presented for the development of sustainable biofuels production methods for promise for accelerating a shift away from an unsustainable approach to possible sustainable production practices or a sustainable social, economic and environment. This article presents an extensive literature review of the biomass-based renewable energy potential in Pakistan based on current energy scenario and future perspectives. It also highlights the availability of the indigenous and local biomass resources and potential biomass conversion technologies to convert such resources to bioenergy. The drivers for utilization of indigenous biomass resources in future energy mix and challenges regarding awareness among stakeholders and R\&D to fill knowledge gaps are economically restraints. The article concludes with suggestions on future directions and policies for effective implementation of biomass based renewable energy production.
\end{abstract}

Keywords: future energy mix, gasification, agriculture residues, waste, biofuels

\section{Introduction}

The world's energy primarily depends upon fossil fuels and consumption is expected to increase rapidly. It will cause depletion of non-renewable fossil fuel resources, global warming and future energy security. Numerous technologies and initiatives are under way to partially replace nonrenewable resources with renewable resources and reducing fossil fuel dependency and greenhouse gas emission. Bioenergy cannot play a vital role to replace petroleum-based products with renewable alternatives, but it can also provide additional energy. The energy shortages in the form of electricity and gas have a direct impact on basic utilities as well as on the industrial economy [3]. In Pakistan, the cost of fossil fuel is one of the primary reasons for the energy crisis, since the domestic consumers and the local power industry utilized natural gas and furnace oil to generate heat and electricity [4]. To address such issues in the developing countries like Pakistan, biomass is considered as a potential resource. It is abundantly available in considerable quantities within the country. The renewable energy sources are interesting due to their low environmental impacts and providing the eco-efficient solution for developing and developed countries. European Union (EU) is generating approximately $71 \%$ of electricity from the renewable energy sources $[5,6]$. 
Biomass as a flexible resource of renewable energy can play a vital role to meet the global demand profiles in energy sectors like electricity, buildings and transport. Among renewable energy, biomass is one the largest energy source that represents $14 \%$ out of $18 \%$ renewable energy in global energy mix [7]. Currently, biomass represents about 10\% (50 EJ) of global total primary supply of energy and contributed $370 \mathrm{TWh}$ of electricity production in 2012 [8]. It is interesting to note that the final product from biomass conversion varies significantly based on different regions, i.e. wood fuel and charcoal for domestic heating and fuel in small scale industries in Asia and Africa, various liquid biofuels in Americas, and polygeneration of biofuels, heat and power production in Europe. The regions with large biomass resource availability also have substantial share of bioenergy reflecting in their total energy mix. Based on World's biomass energy data, Figure 1 shows the distribution of different biomass resources as global primary energy supply. According to IEA, biofuels have potential to meet about $27 \%$ of global transportation fuel requirement by 2050 that shows biofuels have considerably large potential to be expanded for future sustainability. The electricity generation accounts for $1.5 \%$ of global electricity production. Figure 2 shows biomass-based electric power generation in different regions from 2014 to 2016 and also forecast production till 2020 [9].

The developed countries are utilizing waste streams in the energy system as feedstock for a renewable energy production. However, the developing countries like Pakistan are still lagging behind the right methodology and execution of biomass as an alternative renewable energy resource. Currently, about $18 \%$ of the global total energy consumption comes from the renewable energy resources including biomass, hydro power, wind and solar energy [10]. Pakistan is one of the countries that is experiencing a severe energy crisis leading to adverse social and long term economic problems [11-13]. However, the country is focusing to utilize available indigenous sources, like biomass, solar, wind energy and hydro-power potential in order to meet the growing energy demands. According to Economic Year Book of Pakistan 2010-2016, the percentage consumption of energy (annually) from various resources e.g. oil, gas, coal, hydro and nuclear is depicted in Figure 3 [14].

Energy consumption is increasing steadily with increasing population in Pakistan. Previously Pakistan was utilizing local energy sources and later to overcome the energy shortage oil was imported for commercial industries [15] but still, energy needs are not fulfilled. Pakistan will have to endeavour for the alternative energy survival due to increased dependence on imported oil, electricity and liquefied petroleum gas (LPG) which has been shown in Figure 3 as annual consumption growth rate with variable ratios for oil, gas, LPG, coal, wind electricity, nuclear and hydral electricity respectively. In Pakistan, more than $60 \%$ of the population economy is related with agriculture and about $62 \%$ population living in rural areas depends on traditional biomass as a primarily source for cooking and space heating at the household level [13,16-22]. In rural areas of Pakistan wood and animal waste are major biomass sources for energy needs [23]. Modern biomass or liquid biofuels (such as ethanol and biodiesel) used mostly for transportation 
and for generation of electricity are emerging energy alternatives in developing industries. Rural population in Pakistan has limited access to fossil fuel based energy resources and people rely on traditional methods of using wood, animal dung and crop waste for domestic fuel [24]. Renewable energy is expected to play a crucial role in Pakistan's future energy-demands [25]. Modern bio-energy technologies are crucial for Pakistan to utilize the available agricultural residue as renewable resource which may serve a supplementary role in completing the energy demands of the country.

\section{Indigenous biomass resources}

The organic matter in the form of crops residue, wood and animal wastes had stored solar energy in it by photosynthesis process [27-31]. Human beings are using biomass as a source of energy in the form of wood for heating homes and to cook food. In Pakistan like other countries, biomass plays an important role in rural economy as replacement to fossil fuels as the primary energy source. However, for commercial activities, there should be a significant potential source of energy [32]. Biomass is the $4^{\text {th }}$ largest source of energy and provides almost $10 \%$ of the global primary energy supplies, and could be in solid, liquid or gaseous form. Figure 4 shows a comparison of electricity generation from biomass in Pakistan during 2015 to the biomass based electricity generation worldwide [37]. Biomass used for energy production, primarily composed of cellulose, hemicellulose and lignin

Due to unawareness and lack of government policies for biomass utilization, huge amount of crops residues are burnt as waste instead to utilize it for production of energy. Biomass in Pakistan is generated from several sources including agriculture crops, forest residues, industrial waste and municipal solid wastes [34-36]. Different types of biomass resources (Figure 5) include [38-41];

- Agricultural residues such as cane trash, bagasse, straws and green agricultural wastes

- Food processing wastes

- Wood from natural forests and woodlands

- Forestry residues

- Industrial wastes, such as black liquor from paper manufacturing

- Sewage

- Agro-industrial wastes, such as sugarcane bagasse and rice husk

- Animal Livestock

- Municipal solid wastes (MSW)

This review will discuss only those sources which are abundantly available in Pakistan for bioenergy production. Potential sources of biomass, its current utilization and technologies for effective utilization for production of energy are listed in Table 1.

Biomass forms solid liquid and gaseous fuels by going through chemical biological as well as physical processes. The aim is to convert the bulky, carbonaceous low energy content waste to a 
fuel. Among the energy resources biomass ranks fourth providing 35\% of the energy mostly in developing countries. Biomass is a sustainable, environment friendly source of fuel. It absorbs carbon dioxide during growing stages and during combustion emits it. Thus, carbon dioxide is recycled and do not add to greenhouse effect. In addition, biomass can be cultivated as energetic crops to be consumed directly without indulging a middle man to supply raw materials

\subsection{Agriculture crops Waste}

Pakistan being an agrarian economy produces tons of farms residue which are potential biomass feedstock for energy conversion. An agricultural residue produces as a by-product from harvesting and processing of a number of crops mainly wheat straw, rice straw, rice husk, cane trash, bagasse and cotton sticks [42]. In Pakistan 26,280,000 hectares' land is under cultivation according to World Bank statistics [40], supporting economy of $62 \%$ of peoples who live in rural area [44]. Most of the crops residue is directly utilized by the people in the countryside for their basic need of energy for cooking.

Pakistan is the $4^{\text {th }}$ major producer of sugar from sugarcane [45], where it is grown on large scale and generates a huge quantity of cane trash during harvesting season along with bagasse production during sugar manufacturing. In year of 2010-11, approximately 63,920,000 metric tons of sugarcane was harvested and trash generation of around 5,752,800 metric tons is recorded which has potential to generate around 9,475 GWh per year as bioenergy [46]. Under the Government of Pakistan regulations, sugar mills are allowed to produce electric power up to $2000 \mathrm{MW}$ from bagasse as fuel for running of sugar mills [47].

Besides cane trash and bagasse cotton sticks form cotton crop is another potential source for production of bio-energy in Pakistan. In order to meet the demand of local and international textile industry, approximately $11 \%$ of total land cultivation area is reserved for cotton production. Approximately 1,474,693 metric tons of cotton sticks residue was reported in year $2011[48]$.

\subsection{Forest wood residues}

For the time being people rely on wood for cooking and heating their homes. People collect woody sticks and save them to be utilized for burning in cooking stoves [55]. People in northern areas of Pakistan till now rely on wood from forest for cooking and heating purposes. Forest residue comprises the small branches, trees, tops and unused wood left behind after cutting and cleaning of forests. Out of total available land, $5.2 \%$ is covered with forest, which is about 4.224 million hectares' area [56].

Forest residue, a biomass source is environmentally beneficial and can provide significant amount of total bioenergy which is almost $80 \%$ of the total energy consumption in Pakistan from biomass resources [57]. 


\subsection{Animal Waste}

Besides agriculture crops residue animal waste is also used as energy source for burning or cooking purpose. The animal waste is generally termed as manure and contains organic matter which on further processing can be directly converted into biogas. According to the literature survey in Pakistan, approximately 368,434,650 metric tons of manure is generated annually [58]. In many rural areas of Pakistan, small scale anaerobic digestions are used to convert animal manure to biogas for household and small industries. In urban areas of the Pakistan many cattle farms are producing a huge amount of manure which is used as fertilizer in the agriculture sector for soil fertility [59-60].

\subsection{Municipal Solid Waste}

Pakistan is among those countries which are facing the problem of environmental concerns regarding the health issues due to mishandling of municipal solid waste (MSW). MSW comprises the organic matter as well the inorganic metals and can be processed through various methods to utilize for energy generation. According to literature survey Pakistan, MSW with a calorific value of about $6.89 \mathrm{MJ} / \mathrm{Kg}$ per annum [61] which can be processed for power generation in capacity around 13,900GWh annually. In Pakistan major cities like Islamabad, Lahore, Karachi and Multan have industries parks, where huge amount of MSW is produced having a great potential for power generation [62]. MSW includes the industrial wastes as well as commercial and household wastes. However, this potential source of power generation is wasted due to unawareness in proper collection and becoming a source for different diseases instead of an opportunity.

\section{Biomass conversion technologies}

Biomass wastes are effectively converted into bioenergy and biofuels by using various biochemical and thermal technologies including anaerobic digestion, gasification and pyrolysis shown in Figure 6. It is an efficient way to manage the waste material and convert it into a valuable product. Biomass can be utilized for electricity generation and production of valuable chemicals using Fischer-Tropsch reaction. Biomass in the form of MSW is getting recognition worldwide as a potential source for energy generation. Moreover, integration of biomass conversion $t$ bioenergy is an effective way of waste management for environment protection.

\subsection{Thermal conversion technologies}

During thermal conversion processing, biomass feedstock is processed to bioenergy by heating on different temperatures yielding solid, liquid fuels and gases. These decomposition processes take place both on small scale and large scale and provides sufficient bioenergy to overcome the power requirements. 


\subsubsection{Pyrolysis}

Chemical composition of biomass like cellulose hemicellulose and lignin determines the pyrolytic properties. They go through a series of reactions to produce a variety of different products. The distribution of products depends on the reaction conditions. Biomass and waste material adds up to $10 \%$ of the total energy supply of the world. [54]. At temperature below 300 ${ }^{\circ} \mathrm{C}$, pyrolysis of cellulose decreases the molecular weight, water generation, formation of carbon dioxide, carbon monoxide and char. At temperature between 300 to $500{ }^{\circ} \mathrm{C}$, depolymerization of molecules to anhydrous glucose occur that finally converted to tarry pyrozylate. At even higher temperatures the anhydrous sugar go through fission, dehydration, disproportionation and decarboxylation reactions giving volatile and light weight gases and other products. The agricultural waste and organic waste are common raw materials for pyrolysis in Asian countries [63-67].

Biomass feedstock undergoes thermal decomposition at high temperature of $500-800^{\circ} \mathrm{C}$ in absence of oxygen yields biogas, liquid (biofuels) and solid (char) products [68]. The amount of yielding products depends upon temperature. Low temperature yields solid medium favours liquid while high temperature yield the biogas [69]. Literature survey on pyrolysis provides information that $40-75 \%$ of its major products is biofuel [70-73].

\subsubsection{Combustion}

During combustion, biomass feedstock is directly combusted at a very high temperature of 800$1000^{\circ} \mathrm{C}[74]$ and hot flue gases are utilized to produce steam for electricity generation using turbines [50]. Biomass combustion is not only the oldest form of combustion used by humanity, but it is also one of the most complex combustion systems to manage since it involves the use of solid fuels in a multi-phase reaction system with extensive interaction between the thermal and mass fluxes, processes that have only recently been properly analysed and used in simulations to design efficient combustion systems.

\subsubsection{Gasification}

Biomass decomposed to gaseous form through a process called gasification. In this process biomass undergoes through thermal decomposition by incomplete combustion into combustible gas mixture (comprises hydrogen, methane, carbon dioxide, carbon monoxide, nitrogen and some water vapours) [76]. By gasification very low yield of gas is produced and utilized on house fuel engines and in laboratory for different chemical transformations [77, 154].

Gasification is similar to pyrolysis but carried out at high temperatures to control the gas production [50]. The gases formed are known as producer gas and are a mixture of methane hydrogen carbon monoxide nitrogen and carbon dioxide. Biomass gasification is recently introduced to enhance the efficiency of the process and reduce input cost with the help of gas 
turbine technology. Up to $50 \%$ of efficiency can be achieved by combined-cycle gas turbine systems. Here waste gases are recycled to produce steam for use in a steam turbine.

\subsection{Biochemical Decomposition}

The organic matter in biomass is decomposed by the microorganism in presence or absence of oxygen to generate biogas (Eq. 1). Microorganisms can efficiently breakdown the chemical structure of organic matter and convert it into biogas as a simple chemical conversion.

$$
\mathrm{C}_{6} \mathrm{H}_{12} \mathrm{O}_{6} \longrightarrow 3 \mathrm{CO}_{2}+3 \mathrm{CH}_{4} \quad-\cdots-- \text { Eq. } 1
$$

In recent decades, much research has been done in Pakistan by utilizing vast amounts of agricultural lignocellulosic biomass and animal manure and its potential conversion into different high value products including bio-fuels, value added fine chemicals and cheap energy sources for microbial fermentation and enzyme production [78-79].

\subsubsection{Anaerobic digestion}

Biogas is generated from biomass feedstock in the absences of oxygen with the help of microbial activity. Both on domestic and industrial level biomass waste are processed to convert it in valuable biogas which is a mixture of methane, hydrogen, carbon dioxide and traces of other gases. A typical digester is used to digest the biomass by microorganism and to convert it in biogas which can be directly used for cooking as well as in gas engines on industrial scale [8081].

\subsubsection{Fermentation}

Fermentation is a biochemical process that involves hydrolysis of sugars by the activity of microorganisms especially bacteria into ethanol and the process is termed as fermentation. In various countries of the world, fermentation is carried out on an industrial scale for the production of bioethanol in very high yields. Biomass feedstock used in this process is majorly sugar and starch crops, as $60-70 \%$ corn starch used globally for ethanol production [82]. However, use of lignocellulosic biomass is desired to avoid the fuel vs. food competition.

\subsubsection{Transesterification}

Biodiesel is produced through catalytic transesterification of bio-oil. Variety of vegetable oil feedstock including rapeseeds, soya bean, mustard, sunflower, hemp and palm oil as well animal fat is utilized for the production of biodiesel on an industrial scale [83]. During the reaction, catalyst may be an acid, base or an enzyme which is immobilized on a substrate to increase the rate of reaction.

\section{Drivers and significance of biofuels}

We are living in era of technology, where energy is the main driver in the development of countries. Due to growing population and urbanization, energy demand becomes more than production. This deficit in energy cannot be covered by only relying on fossil fuels reservoirs. 
Thus, new energy sources need to be discovered and utilized in order to overcome the energy crisis.

Pakistan is also facing the energy crisis due to depletion of energy reservoirs and increasing energy demand. So, there is need for alternative energy sources. Concept of bioenergy from biomass become reality in different countries around the world (Table 2) to fulfil the increasing demand of energy due to some of its specific properties [84-85];

- Reducing greenhouse gas emission

- Widely available source and flexible in application

- Rural economy diversification

- Reduce land degradation

- Accessible energy

Pakistan and its neighbouring countries have focused on utilization of biomass for bioenergy with supporting research in this field (Table 3). Bioenergy from biomass not only provides energy to compete for the energy demands but also help in handling the waste of industries, commercial and household in a proper way. Effective management of waste is essential to reduce spread of diseases and other environmental related issues [86].

Concept of bioenergy from biomass not only provides energy but it also helps to diversify the economy of a country and support and developed new industries in developing countries. Utilization of biomass for bioenergy is expected to strengthen the agricultural economy as well [87].

\subsection{Biogas}

Anaerobic bacteria decompose the waste organic matter to convert it into biogas. Biogas comprises of methane (majorly), carbon dioxide and traces of other gases. Biogas formed during anaerobic digestion is respiratory product of decomposers, but being combustible it can be utilized as energy source [106]. It is naturally produced in rice paddies, swamps and in the sediments of lakes and oceans where anaerobic digestion takes place. It can also be produced in animal manure when remains in wet condition. In Pakistan's rural areas, where large amount of crops residue and cattle waste is available, have potential to produce biogas on small scale [107]. Small biogas plants are introduced there for household activities; also on small industries, it could provide enough energy to run them easily.

Literature survey reveals that 5357 biogas plants are installed and working in the whole country and have the potential of biogas production about 12-16 million $\mathrm{m}^{3} /$ day that can support the population living in rural areas for cooking purpose [108-109].

\subsection{Transport fuels}


Besides the industrial needs for energy, transportation sector is highly dependent on energy from liquid fossil fuels and transportation is the main consumer of petro-fuels in Pakistan [110]. Biofuels are liquid fuels mostly synthesized from different oils extracted from number of plants and from the crops residues processed as waste through strategic methods [111]. A number of biofuels are synthesized worldwide including biodiesel, bioethanol, gasoline, butanol etc. But in Pakistan biodiesel and bioethanol is can act as an alternative to fossil fuel.

\subsection{Biodiesel}

It is the liquid fuel mainly a fatty acid alkyl ester produced from the processing of waste oil from household and from oil producing plants. Major plants which contribute for the production of biodiesel include corn, canola, soya bean, peanut sunflower, mustard seeds and avocado. Recycling of cooking oil and animal fats also yields biodiesel [112].

About $70 \%$ of Pakistan's overall geographical area lay coarse, thus providing an opportunity to cultivate inedible oil-yielding vegetation that in turn is converted to biodiesel. Thus, it is necessary to develop plant-based biodiesel productions in Pakistan, which will be valuable for the improving socio-economic settings of the country. To use biodiesel as substitute energy source in Pakistan, the AEDB has verbalized policy recommendations, the primary aims of which are to minimize the bill of imported fuel of the country, address the demand of raw material for biodiesel which will be the prime goods for biodiesel fabrication, and promote a pollution-free environment. Also on 14th Feb. 2008, the Economic Coordination Committee (ECC) of the National Cabinet has permitted the strategy for the use of biodiesel as an alternate energy source in its conference. Striking points of the dogma are as follows:

1. AEDB shall be the primary coordinating and facilitating body for the National Biodiesel Program.

2. Gradual introduction of biodiesel fuel blends with petroleum diesel so as to achieve a minimum share of $5 \%$ by volume of the total diesel consumption in the country by the year 2015 and $10 \%$ by 2025 .

3. The Ministry of Petroleum \& Natural Resources shall come up with the fuel quality standards for B-100 and blends up to B-20.

4. Oil Marketing Companies (OMCs) are to purchase biodiesel (B-100) from biodiesel manufactures; and sell this biodiesel blended with petroleum diesel (starting with B-5) at their points of sale

Esterification of fatty acids plants oil and animal fats in the presence of alcohol and catalyst yield biodiesel used in replacement of petro fuels in transportation [113-116]. Biodiesel favours the transportation over petrofuels due to following benefits [82];

- Eco-friendly 
- Can be utilized in any diesel engine without any modification

- Contains no petroleum, but can be blended with conventional diesel engines

- Clean burning alternative fuel

- Degradable, non-toxic and free from sulphur \& lead

\subsection{Bioethanol}

Fermentation of waste residue using bacteria/Yeast can produce bioethanol which is a valuable alternative to gasoline for internal combustion engines [117,126]. Biomass has significant potential for bioethanol production including the crops residues and municipal solid waste [118]. Literature survey reveals number of methods reported for bioethanol production worldwide in recent decades [119-124], where bioethanol proves to be the best fuel for internal combustion engine. Currently, bioethanol is produced on large scale on a large from sugar-containing raw materials including sugarcane and starch based crops [125].

\section{Potential Impact of bioenergy on various sectors}

\subsection{Bioenergy impacts on households}

In Pakistan, around $62 \%$ population is living in rural areas, where people fulfil their energy demand by relying on traditional fuels like firewood, animal dung and crops residue for household cooking and heating purposes [127]. Biogas energy has a good prospect in rural areas as well in urban areas as an efficient fuel for cooking stoves Whereas, dung-waste has also the potential to produce approximately 12 million $\mathrm{m}^{3} /$ day of biogas which can provide average energy of 28 million people of rural areas [128]. Besides private sector, almost 4137 biogas units were installed by Directorate General of New and Renewable Resources (DGNRER) under Ministry of Petroleum and Natural Resources throughout the country by a scheme. These units have the potential to provide 3000 and 5000 cubic feet of biogas per day for heating and lighting purposes [129]. 76\% household in Pakistan depends on biomass resources due to unavailability of other energy alternatives [130]. As total biomass energy consumption in Pakistan was estimated to be 954.56 PJ by the year 2010, where 711.75 PJ (76\%) is consumed by the household sector.

\subsection{Bioenergy impacts on industrial sector}

On industrial scale, petroleum products are primary fuels for running the industries, wherever the introduction of bioenergy from biomass as a new source of energy is now focused as an energy alternative. In Pakistan about 23\% (209.34PJ) of the total energy consumption is reserved for industrial sector [131]. Pakistan is ranked at $10^{\text {th }}$ number in list of countries using biomass as energy source in industries (Table 4). The primary biomass source for industrial scale is bagasse from sugarcane which can be used by many industries as energy source directly or indirectly. About $70 \%$ of the total bagasse is directly used as fuel for condensation-extraction steam turbines (CEST) in sugar industry itself while remaining is utilized indirectly in different 
industries as fuel for combined heat and power ( $\mathrm{CPH})$ generation system [132]. Moreover, agricultural residues like rice husk, wheat, corn stalks and cotton sticks etc. contributes about 85.5PJ biomass energy for the industrial sector. But most of the crops residues are directly used as burning fuel in bricks kilns [133].

\section{Benefits of bioenergy over fossil fuels for Pakistan Economy}

Urbanization and developments in industrial sector and structures led to environmental problems. Petroleum products are the major energy source in almost every industry as well as primary fuel for transportation. Presence of volatile organic compounds (VOC) cause emission of harmful greenhouse gases (GHG), thus contributing seriously in environmental problems [138]. A long-term solution to these problems is required for a sustainable development. In this regard, renewable energy is emerging as efficient and effective solution for environmental issues [136]. Bioenergy from biomass is getting the attention in recent years. Bioenergy has numerous benefits for environment as follow [137];

- Reducing GHG emissions

- Renewable or biodegradable energy

- Providing economic development as well employment opportunities

- Supporting food- processing and agriculture industries

- Cost saving and abundantly available

- Reduce landfills

- Energy reliability and security

- Reduce dependence on fossil fuels

- Can be used to create different products (i.e. ethanol)

\section{Exploitation of bioenergy in Pakistan}

Biomass will be a significant source of alternative energy in future. In order to achieve sustainable development in bioenergy, many challenges are there to face and resolve as enlisted in Table 5 [138-139]. Taking the hurdles under consideration biomass utilization for bio-energy production, couples of things are required special attentions.

Awareness on different sectors: There is a need to highlight those success stories of biomass utilization for energy in urban and rural areas, which can be replicated [140]. It will be the most critical and crucial step towards making sustainable bioenergy program successful. Public organizations and media should be actively involved to provide necessary information and general awareness regarding the impacts of bioenergy from biomass through specialized agencies and training facilities. Farmers must be encouraged to adopt the biomass based bioenergy technologies for sustainable agriculture. 
Science and technology (S\&T) developments: Science and technology centres for bioenergy and clubs should be launched for the promotion of S\&T in all educational institutes as well the establishment of museum and display centre for science and technology. Mirza et al. [141] pointed out flaws by suggesting that the community participation is only restricted to just a few demonstrated projects, which resulted in a lack of coordination among departments/institutions responsible for renewable energy development and commercialization. Technical education infrastructure should be efficiently utilized to promote the concept of sustainable development through the introduction of courses dealing with renewable energy technologies. Trained S\&T policy making professionals are needed to be involved in policy making process at all levels [142].

Research and development $(\boldsymbol{R} \& \boldsymbol{D})$ : There is need for focused research and development (R\&D) to play a vital role in the development of sustainable bioenergy so that the cost can be reduced and the technology is made affordable for the poor households. The professional educational institutes and universities have to play a very important role to accept the challenge and to introduce the subject of renewable energy and other emerging technologies as course in different degree programs. Biomass potential for bioenergy should be considered as capacity issues in govt. and public sector institutions, private sector and also among financial institutions [143].

\section{Promotional strategies of biomass for energy}

Besides conventional sources for bioenergy, there is a need to find other resources to overcome the demand and supply issue of energy. Pakistan is enriched with number of easily available biomass resources which can be utilized in good way to generate energy. In recent studies, Longrange Energy Alternative Planning system (LEAP) model was used to track production and consumption of non-woody crops and livestock Table (crops and animals) waste biomass in Pakistan and its perspective as renewable energy in coming future, where yield of bagasse rises up to 152.2 trillion with greatest share comparatively in the category of major crops as shown in Table 6 [144]. Here are some suggestions to utilize other alternative biomass available in Pakistan;

City wastes: In Pakistan, urban areas are producing around of 55,000 tons of solid waste on daily basis, which if collected and processed properly can be utilized for energy production. A huge amount of waste is burnt on open land which causes emission of GHG and creating the environmental pollution as well as spreading different diseases. If this waste is burnt properly then its heating energy can be utilized for production of electricity. Through proper landfill techniques and managing solid wastes a reasonable amount of heat and electric power can be generated. 
Poultry Litter: Poultry-based farms have broad industrial networking in Pakistan. A huge amount of poultry litter especially chicken litter both from layer-chicken and broiler-chicken generated on daily basis. With special attention, such source can be utilized for bioenergy production. It is estimated that 15.0 million layer-chicken and 528 million broiler-chicken are expected to be produce between 2003-2004 year including share of $68 \%, 22 \%, 6.5 \%$ and $3.5 \%$ of Punjab, Sindh, KPK and Baluchistan respectively. Literature survey reveals that 15 tons per year chicken-litter is scraped out from a shed of 3000 chicken-birds from poultry farms in Pakistan. If this waste-litter processed in a technical way can provide enough energy required for generation of $40 \mathrm{MW}$ of electricity on daily basis.

Animal slurry: According to livestock census of 2000, and Federal Bureau of Statistics (FBS) [145] of Pakistan, there are 46.69 million of animals including buffaloes, cows and bullocks producing 700 million Kg dung per day. Hassan et al [146] estimated that besides 50 million Kg of bio-fertilizers, 17.5 million $\mathrm{M}^{3}$ biogas can be produced through bio-methanation from animal dung per day. As till now biogas from animal dung is produced at local levels but it can take up to commercial basis if government makes some policies against it.

\section{Future directions}

In Pakistan biomass will be a significant alternative energy source in future. In order to overcome the energy shortage researcher and scientist are now focusing more on biomass for bioenergy production due to its availability for energy generation [147-148]. The Government of Pakistan in collaboration with different countries has made new policies and projects on bioenergy production from biomass [149] that are under progress in different universities, Govt. and privative organizations shown in Table 7. Here are some policies and projects are highlighted which are currently in progress;

> Pakistan has made a policy to add RSE (Renewable \& Sustainable Energy) for energy production; Alternative Energy Development Board (AEDB) has been established to contribute $5 \%$ energy production from renewables. AEDB is now working on energy production project by using huge resource of biogas near Karachi in Landhi cattle colony to produce $30 \mathrm{MW}$ which is being funded by New Zealand.

$>$ A letter of intent was issued for $12 \mathrm{MW}$ power plant established for utilization of agricultural wastes in Jhang and 9 MW plant is going to be installed at Pak Ethanol Pvt. Ltd., Sindh.

$>$ In coming years 5000 biogas units will be installed all over the country by Pakistan Counsel of Renewable Energy Technologies (PCRET). 
Government has invested 356 million to import 1400 biogas plants [150].

Biomass/ Waste-to-Energy Following Biomass/Waste-to-Energy projects are in various stages of implementation under IPP mode:

- $\mathrm{M} / \mathrm{s}$ SSJD (12 MW) Sindh

- M/s Lumen Energia (12 MW Shahkot)

- Punjab M/s Biomass Power Generation Limited (12 MW), Faisalabad M/s Green Sure Environmental Solutions (12 MW), Mardan, KPK

$>$ Also, framework for power Co-generation 2013 (Biomass/Bagasse) was approved by Economic Coordination Committee (ECC) for bagasse/biomass based sugar industry projects. 1500-2000 MW of power is expected to be generated in next 2-3 years [151].

$>$ Centre for Advanced Studies in Energy at NUST (CAS-EN) is working on project entitled; "Biomass Resource Availability Study" funded by International Finance Corporation a subsidiary of World Bank Group (IFC-WBG) [152].

\section{Conclusions}

Biomass is an emerging renewable resource for bioenergy production to meet the future energy demand in the developing countries. Pakistan as a developing country also needed to put forth its efforts for potential production of bioenergy from biomass to tackle the energy crises. This article highlights the importance of bioenergy production from biomass and areas for more attention on development of infrastructure for biomass conversion to bioenergy, research works and its availability on all scales. Considering the importance of bioenergy from biomass some technological steps has been taken by the govt. However, govt. and private sectors are required to act on emergency basis for producing more bioenergy to cut the energy deficit in the country. In addition, the article has a lot of significance for Pakistan's rural areas where considerable amount of biomass resource in the form of indigenous agricultural wastes is available. It is important to identify suitable thermal or bio-chemical conversion techniques for different biomass producing flexible fuels like char, pyrolysis vapours, bio-oil or synthesis gas which could be further converted to methane, dimethyl ether (DME), methanol, hydrogen etc. The flexible fuels may then be utilized for combined heat and power production or converting them to vehicle fuels. This article will provide base for future evaluation of potential biofuel, electricity or thermal energy production at distributed small scale that may be sufficient to meet energy requirement in the developing countries globally.

\section{Acknowledgment}


Authors have no conflict of interest and would like to acknowledge the National University of Sciences \& Technology (NUST), Pakistan.

\section{References}

[1]. Eugene D. Coyle and Richard A. Simmons. Understanding the Global Energy Crisis. Purdue University Press e-books 2014.

[2]. Holdren JP. Population and the Energy Problem, Population and Environment. 1991;231-55.

[3]. S. Amin. Solution for energy crisis in Pakistan. IPRI Publications 2013.

[4]. M. Asif. Sustainable energy options for Pakistan. Renew Sustain Energy Rev 2009; 13:903-909.

[5]. Cunado J. and Gracia FP. Oil prices, economic activity and inflation: Evidence for some Asian countries. Q Rev Econ Financ 2005;45(1):65-83.

[6]. Global status report. REN21. Renewable Energy Policy Network for the $21^{\text {st }}$ Century; 2012. Available at: http://www.map.ren21.net/GSR/ GSR2012.pdf.

[7]. World Energy Council report, 2016. World Energy Resources Bioenergy (2016). https://www.worldenergy.org/wpcontent/uploads/2017/03/WEResources_Bioenergy_2016.pdf

[8]. International Energy Agency (IEA) statistics book, 2016. Renewables Information 2016 EDITION. ISBN PRINT 978-92-64-25866-2 / PDF 978-92-64-25867-9

[9]. International Energy Agency, 2015. Medium-Term Renewable Energy Market Report 2015, OECD/IEA, Paris.

[10]. Kumar A, Kumar K, Kaushik N, Sharma S and Mishra S. Renewable energy in India: current status and future potentials. Renew Sustain Energy Rev 2010;14(8):2434e42

[11]. PC. Pakistan in the 21st century: Vision 2030. Planning Commission, Government of Pakistan 2007.

[12]. A. W. Bhutto, A. A. Bazmi and G. Zahedi. Greener energy: Issues and challenges for Pakistan-Biomass energy prospective. Renew Sustain Energy Rev 2011; 15:3207-3219.

[13]. Economic survey of Pakistan, Islamabad. Government of Pakistan Ministry of Finance 2010. 
[14]. Pakistan Year Book 2015. Government of Pakistan Ministry of Finance, Economic Affairs, Revenue, Statistics and Privatization, Islamabad. Available at: www.pbs.gov.pk.

[15]. A. Arshad, M. Zakaria and Xi Junyang., Energy prices and economic growth in Pakistan: A macro-econometric analysis. Renew Sustain Energy Rev 2016; 55:25-33

[16]. Sahir MH and Qureshi AH. Assessment of new and renewable energy resources potential and identification of barriers to their significant utilization in Pakistan. Renew Sustain Energy Rev 2008; 12:290-298.

[17]. Malik A. How Pakistan is coping with the challenge of high oil prices. Pak Dev Rev 2007;46(4):551-75.

[18]. Usama Perwez, Ahmed Sohail, Syed Fahad Hassan and Usman Zia. The long-term forecast of Pakistan's electricity supply and demand: An application of long range energy alternatives planning. Energy 2015;93:2423-2435

[19]. Pakistan Year Book 2013. Government of Pakistan Ministry of Finance, Economic Affairs, Revenue, Statistics and Privatization, Islamabad. Available at: www.pbs.gov.pk.

[20]. Dr. Zafar Fatmi, Dr. M. Masood Kadir, Dr. Waqar Ahmed and Dr. Ambreen Kazi. Situation Analysis of Household Energy Use and Indoor Air Pollution in Pakistan. Department of Child and Adolescent Health and Development WHO 2005.

[21]. Saad Butt, Ingo Hartmann and Volker Lenz. Bioenergy potential and consumption in Pakistan. Biomass Bioenergy Rev 2013;58:379-389.

[22]. Inayatullah Jan. What makes people adopt improved cook stoves? Empirical evidence from rural North West Pakistan. Renew Sustain Energy Rev 2012; 16:3200-3205.

[23]. Mirza Umar K, Ahmad Nasir, Majeed Tariq and Harijan Khanji. Wind energy development in Pakistan. Renew Sustain Energy Rev 2007;11(9):2179-90.

[24]. Syed S. Amjid, Muhammad Q. Bilal, Muhammad S. Nazir and Altaf Hussain. Biogas: renewable energy resource for Pakistan. Renew Sustain Energy Rev 2011; 15:2833-2837.

[25]. M. Saif Ur Rehman, Naim Rashid, Ameena Saif, Tariq Mahmood and Jong-In Han. Potential of bioenergy production from industrial hemp (Cannabis sativa): Pakistan perspective. Renew Sustain Energy Rev 2013;18:154-164.

[26]. Perez MG, Chaala A and Roy C. Vacuum pyrolysis of sugarcane bagasse. J Anal Appl Pyrolysis 2002;65:111-136.

[27]. Demirbas A. Biomass resource fascilities and biomass conversion processing for fuels and chemicals. Energy Convers Manage 2001;42:1357-1378. 
[28]. McKendry P. Energy production from biomass (Part 1): Overview of biomass. Bioresource Technol 2002;83:37-46.

[29]. Shaheen Rafi Khan. Viewing Biofuel (Ethanol) Prospects in Pakistan through a Sustainable Development Prism. SDPI Research and News Bulletin 2007;14(3).

[30]. C. Baskar. Biomass Conversion. Springer-Verlag Berlin Heidelberg 2012.

[31]. Peter Quaak, Harrie Knoef and Hubert E. Stassen. Energy from Biomass: A Rev Combust and Gasific 1999;23:422.

[32]. A. Mahmood, N. Javaid, A. Zafar, R. Ali Riaz, S. Ahmed and S. Razzaq. Pakistan's overall energy potential assessment: comparison of LNG, TAPI and IPI gas projects. Renew Sustain Energy Rev 2014;31:182-193

[33]. Klass D. Biomass for renewable energy and fuels. Encyclopedia of energy. New York: Elsevier Inc 2004.

[34]. H.B. Goyal, Diptendu Seal and R.C. Saxena. Bio-fuels from thermochemical conversion of renewable resources: A review. Renew Sustain Energy Rev 2008;12:504-517

[35]. Bridgewater A. V. Principles and practice of biomass fast pyrolysis processes for liquids. J Anal Appl Pyrolysis 1999;51:3-22.

[36]. Peter McKendry. Energy production from biomass (part 1): Overview of biomass Bioresource Technol 2002;83:37-46

[37]. (OICCI): Overseas investors chamber of commerce \& investments Pakistan. Energy sub-committee NEPRA's State of Industry Report 2015.

[38]. L.S. Esteban and J.E. Carrasco. Biomass resources and costs: Assessment in different EU countries. Biomass Bioenergy 2011;35:21-30.

[39]. D. Alfonso, C. Perpiñá, A. Pérez-Navarro, E. Peñalvo, C. Vargas and R. Cárdenas. Methodology for optimization of distributed biomass resources, evaluation, management and final energy use. Biomass Bioenergy 2009;33(8):1070-1079.

[40]. Matti Parikka. Global biomass fuel resources. Biomass Bioenergy 2004;27(6):613-620

[41]. Suresh Chauhan. Biomass resources assessment for power generation: A case study from Haryana state, India. Biomass Bioenergy 2010;34(9):1300-1308.

[42]. J. Kumar Saini, R. Saini, and L. Tewari. Lignocellulosic agriculture wastes as biomass feedstocks for second-generation bioethanol production: Concepts and recent developments Biotech 2015;5(4):337-353. 
[43]. World Bank 2015. Pakistan Development Update Washington, DC. (C) World Bank. https://openknowledge.worldbank.org/handle/10986/22926 License: CC BY 3.0 IGO.

[44]. Government of Pakistan. Economic Survey of Pakistan, Islamabad. Ministry of Finance 2006.

[45]. M. Aamir Iqbal and Asif Iqbal. Sugarcane Production, Economics and Industry in Pakistan. American-Eurasian J. Agric. \& Environ. Sci 2014;14(12):1470-1477.

[46]. Annual report 2014 Pakistan sugar mills association 2014-15 available at: www.psmacentre.com

[47]. Sugar industry allowed to generate 2,000 MW electricity /http://www.jang.com.pk/thenews/nov2005-daily/ 29-11-2005/main/main13.html, accessed on 07 March 2007.

[48]. Pakistan Economic forum III. Draft report 2015. The Pakistan Business Council; available at: http://www.pbc.org.pk.

[49]. Bhattacharya SC, Abdul Salam P, Runqing H, Somashekar HI, Racelis DA and Rathnasiri P. G. An assessment of the potential for non-plantation biomass resources in selected Asian countries for 2010. Biomass Bioenergy 2005;29(3):153-166.

[50]. Zia Ud Din and A. Zainal Z. Biomass integrated gasification-SOFC systems: Technology overview. Renew Sustain Energy Rev 2016;1356-1376.

[51]. Elauria JC, Castro MLY, Elauria MM, Bhattacharya SC and Abdul Salam P. Assessment of sustainable energy potential of non-plantation biomass resources in the Philippines. Biomass Bioenergy 2005;29(3):191-198.

[52]. Zhongfu Tan, Kangting Chen and Pingkuo Liu. Possibilities and challenges of China's foresty biomass resources utilization. Renew Sustain Energy Rev 2015;368-378.

[53]. Tao, Khan, Strezov Vladimir and J Evans Tim. Lignocellulosic biomass pyrolysis: A review of product properties and effects of pyrolysis parameters. Renew Sustain Energy Rev 2016;1126-1140.

[54]. Frank Spellman Forest-Based Biomass Energy: Concepts and Applications. (C) 2012 Taylor and Francis Group LLC.

[55]. Danish M, Naqvi M, Farooq U, Naqvi S. Characterization of South Asian agricultural residues for potential utilization in 'Future energy mix'. ICAE 2015, Abu-dhabi.

[56]. G.o.P. Ministry of Finance. Economic Survey of Pakistan. Available: 〈http:// www.finance.gov.pk/survey/chapters_13/); 2012-2013. 
[57]. Sheikh MA. Renewable energy resource potential in Pakistan. Renew Sustain Energy Rev 2009;13:2696-2702.

[58]. Ravindranath NH, Somashekar HI, Nagaraja MS, Sudha P, Sangeetha G and Bhattacharya SC. Assessment of sustainable non-plantation biomass resources potential for energy in India. Biomass Bioenergy 2005;29:178-190.

[59]. Compendium on Environment Statistics of Pakistan 2010 Federal Bureau of Statistics Government of Pakistan. Available at: http://www.pbs.gov.pk/

[60]. Guerrero LA, Maas G and Hogland W. Solid waste management challenges for cities in developing countries. Waste Manag 2013;33:220-232.

[61]. J. Akhtar and N. Saidina Amin. A review on operating parameters for optimum liquid oil yield in biomass pyrolysis. Renew Sustain Energy Rev 2012;16(7):5101-5109

[62]. AV B. Principles and practice of biomass fast pyrolysis processes for liquids. J Ana Appl Pyrolysis 1999;51:3-22.

[63]. Vladmimir F. Kosov, Vladimir A., Lavrenov, Olga M. Larina and Viklor M. Zaichenko. Use of Two-stage pyrolysis for Bio-waste Recycling. Chem Eng Transact 2016;50.

[64]. S.T. Kumaravel, A. Murugesan and A. Kumaravel. Tyre proylsis oil as an alternative fuel for diesel engines: A review. Renew Sustain Energy Rev 2016;60:1678-1685.

[65]. Anke Krutof and Kelly Hawbodlt., Blends of Pyrolysis oil, Petroleum and other biobased fuels: A review. Renew Sustain Energy Rev 2016;59:406-419.

[66].Güray Yildizi, Frederick Ronsse, Ruben Van Duran and Wolter Prins. Challenges in the design and operation of Processess for catalytic fast pyrolysis of woody biomass. Renew Sustain Energy Rev 2016;57:1596-1610.

[67]. Manoj Tripathi, J.N. Sahu and P. Ganesan. Effect of process parameters on production of biochar from biomass waste through pyrolysis: A review. Renew Sustain Energy Rev 2016;55:467-481.

[68]. Sheikh Adil Edrisi and P.C. Abhilash. Exploring marginal and degraded lands for biomass and bioenergy production: An Indian scenario. Renew Sustain Energy Rev 2016;54:1537-1551.

[69]. Abdur Raheem, Mohammad Yusri Hassan and Rabia Shakoor. Bioenergy from anaerobic digestion in Pakistan: Potential, development and Prospects. Renew Sustain Energy Rev 2016;59:264-275. 
[70]. WT Tsai, MK Lee and YM Chang. Fast pyrolysis of rice husk: Product yields and compositions. Bioresource Technol 2007;98:22-28.

[71]. BB Uzun, AE Pütün and E Pütün. Fast pyrolysis of soybean cake: Product yields and compositions. Bioresource Techn 2006;97:569-576.

[72]. C Ackkgoz, O Onay and OM Kockar. Fast pyrolysis of linseed: Product yields and compositions. J Anal Appl Pyrolysis 2004;71:417-429.

[73]. Erik Dahlquist, Muhammad Naqvi, Eva Thorin, Jinyue Yan, Konstantinos Kyprianidis, Philip Hartwell, 2017. Experimental and numerical investigation of pellet and black liquor gasification for polygeneration plant. Accepted for publication in Applied Energy.

[74]. Muhammad Naqvi, Erik Dahlquist, Jinyue Yan, 2016. Complementing existing CHP plants using biomass for production of hydrogen and burning the residual gas in a CHP boiler. Biofuels. ISSN: 1759-7269. DOI:10.1080/17597269.2016.1153362.

[75]. Singh R, Shukla A. A review on methods of flue gas cleaning from combustion of biomass. Renew Sustain Energy Rev 2014;29:854-864

[76]. L.J.R. Nunes, J.C.O. Matias and J.P.S. Catalão. Biomass combustion systems: A review on the physical and chemical properties of the ashes. Renew Sustain Energy Rev 2015; 235242.

[77]. Muhammad Naqvi, Jinyue Yan, Erik Dahlquist, Salman Naqvi, 2017. Off-grid electricity generation using mixed biomass compost: A scenario-based study with sensitivity analysis. Applied Energy, article in press.

[78]. Asgher, M, Ahmad, Z, and Iqbal H. M. N. Alkali and enzymatic delignification of sugarcane bagasse to expose cellulose polymers for saccharification and bio-ethanol production. Indust Crops Prod 2013;44:488-495.

[79]. Zahid Anwar, Muhammad Gulfraz and Muhammad Irshad. Agro-industrial lignocellulosic biomass a key to unlock the future bio-energy: A brief review. J Radi Res Appl Sci 2014;7:163-173.

[80]. S.S. Amjad, M.Q. Bilal, M.S. Nazir and A. Hussain. Biogas: Renewable energy resource for Pakistan. Renew Sustain Energy Rev 2011;15:2833-2837.

[81]. Jones HB and Ogden EA. Biomass energy potential from livestock and poultry wastes in the Southern United States. Biomass 1984;6:25-35.

[82]. Tan $\mathrm{Z}$ and Lagerkvist A. Phosphorus recovery from the biomass ash: A Review. Renew Sustain Energy Rev 2011;15:3588-602. 
[83]. Abdur Raheem, Mohammad Yusri Hassan and Rabia Shakoor. Bioenergy from anaerobic digestion in Pakistan: Potential, development and prospects. Renew Sustain Energy Rev 2016;59:264-275.

[84]. N.B. Singh, Ashwani Kumar and Sarita Rai; Potential production of bioenergy from biomass in an Indian perspective. Renew Sustain Energy Rev 2014;39:65-78

[85]. IEA: World Bioenergy Association (WBS). Global bioenergy statistics 2016. Available at: http: www.iea.org/stas/index.asp

[86]. Naim Rashid, Muhammad Saif Ur Rehman and Jong-In Han. Recycling and reuse of spent microalgal biomass for sustainable biofuels. Biochem Eng Journ 2013;75(15):101-107.

[87]. Omer Rauf, Shujie Wang, Peng Yuan and Junzhe Tan. An overview of energy status and development in Pakistan. Renew Sustain Energy Rev 2015;48:892-931.

[88]. P.K. Halder, N. Paul and M.R.A. Assessment of biomass energy resources and related technologies practice in Bangladesh. Renew Sustain Energy Rev 2014;39:444-460.

[89]. Bangladesh Sugarcane Research Institute. Ministry of Agriculture. Government of the People's Republic of Bangladesh, 〈http://www.bsri.gov.bd// [accessed January 2014].

[90]. Department of Agricultural Extension. Government of the People's Republic of Bangladesh. 〈http://www.dae.gov.bd/> [accessed January 2014].

[91]. Bangladesh Agriculture - products. 〈http://www.indexmundi.com/agriculture /?country=bd $\rangle$ [accessed January 2014].

[92]. Apex planet. 〈http://apexplanet.blogspot.com/2012/11/lakkatura-tea-estate-oldest-teagarden.html [accessed January 2014].

[93]. Cotton Development Board (CDB). Government of the People's Republic of Bangladesh. 〈http://www.cdb.gov.bd/> [accessed January 2014].

[94]. Ministry of Finance. Government of the People's Republic of Bangladesh. 〈http://www.mof.gov.bd/en/〉 [accessed January 2014].

[95]. A.S.N. Huda, S. Mekhilef and A. Ahsan. Biomass energy in Bangladesh: Current status and prospects. Renew Sustain Energy Rev 2013;504-517.

[96]. Junfeng L, Runqing H, Yanqin S, Jingli S, Bhattacharya SC and Abdul Salam P. Assessment of sustainable energy potential of non-plantation biomass resources in China. Biomass Bioenergy 2005;29(3):167-177. 
[97]. Mei Qu, Ying Lin, Can Liu, Shunbo Yao and Yang Cao. Farmers' perceptions of developing forest based bioenergy in China. Renew Sustain Energy Rev 2016;58:581-589.

[98]. Ravindranath NH, Somashekar HI, Nagaraja MS, Sudha P, Sangeetha G and Bhattacharya SC. Assessment of sustainable non-plantation biomass resources potential for energy in India. Biomass Bioenergy 2005;29 (3):178-190.

[99]. Moonmoon Hiloidhari, Dhiman Das and D.C. Baruah. Bioenergy potential from crop residue biomass in India. Renew Sustain Energy Rev 2014;32:504-512

[100]. Anil Kumar, Nitin Kumar, Prashant Baredar and Ashish Shukla. A review on biomass energy resources, potential, conversion. Renew Sustain Energy Rev 2015;530-539.

[101]. Bhattacharya SC, Abdul Salam P, Runqing H, Somashekar HI, Racelis DA and Rathnasiri PG. An assessment of the potential for non-plantation biomass resources in selected Asian countries for 2010. Biomass Bioenergy 2005;29(3):153-166.

[102]. Sajjakulnukit B, Yingyuad R, Maneekhao V, Pongnarintasut V and Bhattacharya SC, Abdul Salam P. Assessment of sustainable energy potential of non-plantation biomass resources in Thailand. Biomass Bioenergy 2005;29(3):214-224.

[103]. Elauria JC, Castro MLY, Elauria MM, Bhattacharya SC and Abdul Salam P. Assessment of sustainable energy potential of non-plantation biomass resources in the Philippines. Biomass Bioenergy 2005;29(3):191-198.

[104]. (PRES) Pakistan Renewable Energy Society. Promoting Green Energy for Better Tomorrow. available at: http://www.pres.org.pk/category/reaepakistan/bio-mass/

[105]. Umar K. Mirza, Nasir Ahmad and Tariq Majeed. An overview of biomass energy utilization in Pakistan. Renew Sustain Energy Rev 2008;12:1988-1996.

[106]. Peter Jacob Jørgensen. Biogas-Green energy. Faculty of Agricultural Sciences, Aarhus University $2^{\text {nd }}$ edition, Digisource Danmark A/S 2009.

[107]. S.C Bhattacharya and P Abdul Salam. Low greenhouse gas biomass options for cooking in the developing countries. Biomass Bioenergy 2002;22(4):305-317.

[108]. Akhter P. Country presentations: Promotion of Renewable Energy, Energy Efficiency and Greenhouses Gas Abatement (PREGA). In: Second Regional Training and Planning Workshop on Renew Energy 2004.

[109]. ADB. Islamic Republic of Pakistan: country environment analysis. Asian Development Bank 2008.

[110]. Ministry of Petroleum and Natural Resources, Government of Pakistan. 
[111]. NREL: National Renewable Energy Laboratory. Innovation for our energy future. August 2006. Available at: www.nrel.gov.

[112]. Greg Phal. Biodiesel: Grouping a new energy economy. $2^{\text {nd }}$ edition, Chelsea Green Publishing Company White River Junction, Vermont. August 2008.

[113]. Ma F and Hanna MA. Biodiesel production: A Review. Bioresources Technol 1999;70:1-15.

[114]. Pramanik K. Properties and use of Jatropha curcas oil and diesel fuel blends in compression ignition engine. Renew Energy 2003;28:239-248.

[115]. Schuchardta U, Serchelia R and Vargas RM. Transesterification of vegetable oils: A Review. J Braz Chem Soc 1998;9:199-210.

[116]. Freedman B, Pryde EH and Mounts TL. Variables affecting the yields of fatty esters from transesterified vegetable oils. JAOCS 1984;61:1638-1643.

[117]. Niven RK. Ethanol in gasoline: environmental impacts and sustainability review article. Renew Sustain Energy Rev 2005;9:535-555.

[118]. Mussatto SI, Dragone G, Guimarães PM, Silva JP, Carneiro LM and Roberto IC. Technological trends, global market, and challenges of bio-ethanol production. Biotechnol Adv 2010;28:817-30.

[119]. Demirbas A. Progress and recent trends in biofuels. Prog Energy Combust Sci 2007;33:1-18.

[120]. Sarkar N, Ghosh SK, Bannerjee S and Aikat K. Bioethanol production from agricultural wastes: An overview. Renew Energy 2012;37:19-27.

[121]. Mood SH, Golfeshan AH, Tabatabaei M, Jouzani GS, Najafi GH and Gholami M. Lignocellulosic biomass to bioethanol, a comprehensive review with a focus on pretreatment. Renew Sustain Energy Rev 2013;27:77-93.

[122].Ganguly A, Chatterjee PK and Dey A. Studies on ethanol production from water hyacinth: A Review. Renew Sustain Energy Rev 2012;16:966-972.

[123].Kosugi A, Kondo A, Ueda M, Murata Y, Vaithanomsat P and Thanapase W. Production of ethanol from cassava pulp via fermentation with a surface engineered yeast strain displaying glucoamylase. Renew Energy 2009;34:1354-1358.

[124]. Wei P, Cheng LH, Zhang L, Xu XH, Chen HL and Gao CJ. A review of membrane technology for bioethanol production. Renew Sustain Energy Rev 2014;30:388-400. 
[125]. Oscar JS and Carlos AC. Review: trends in biotechnological production of fuel ethanol from different feedstocks. Bioresources Technol 2008;99:5270-95.

[126]. Limayem A and Ricke SC. Lignocellulosic biomass for bioethanol production: current perspectives, potential issues and future prospects. Prog Energy Combust Sci 2012;38:449_ 67.

[127]. Government of Pakistan. Pakistan Economic Survey 2005-06. Islamabad, Pakistan: Economic Advisers Wing, Ministry of Finance 2006.

[128]. Umar K. Mirza, Nasir Ahmad and Tariq Majeed; An overview of biomass energy utilization in Pakistan. Renew Sustain Energy Rev 2008;12:1988-1996

[129]. Promotion of Renewable Energy, Energy Efficiency and Greenhouse Gas Abatement (PREGA)—Pakistan Country Report. Asian Development Bank 2004.

[130]. Pakistan integrated energy model: International Resources Group for Asian Development Bank and Ministry of Planning and Development Government of Pakistan 2010.

[131]. GOP. Pakistan Economic Survey 2009-10, June. Islamabad, Pakistan: Economic Advisers Wing, Ministry of Finance, Government of Pakistan 2010.

[132]. Larson ED and Kartha S. Expanding roles for modernized biomass energy. Energy Sustain Develop 2000;4:15-25.

[133].Omer Rauf, Shujie Wang, Peng Yuan and Junzhe Tan; An overview of energy status and development in Pakistan. Renew Sustain Energy Rev 2015;48:892-931

[134]. IEA: Energy Statistics 2012. Available at: http: www.iea.org/stas/index.asp.

[135]. Elizabeth Cushion, Adrian Whiteman and Gerhard Dieterle. Bioenergy Development: Issues and Impacts for Poverty and Natural Resource. (C) 2010 The World Bank. Washington DC 20433.

[136]. Ibrahim Dincer. Renewable energy and sustainable development: A crucial review. Renew Sustain Energy Rev 2000;4:157-175

[137]. O. Edenhofer, R. Pichs-Madruga, Y. Sokona, K. Seyboth, S. Kadner, T. Zwickel, P. Eickemeier, G. Hansen, S. Schlömer, Chris. von Stechow and P. Matschoss. Renewable Energy Sources and Climate Change Mitigation. Cambridge University Press 2012.

[138]. Daniela Cristina Momete. Analysis of Sustainable Biomass: A Three-Dimensional Approach. International Conference on Economic Engineering and Manufacturing Systems Braşov 2011. 
[139]. Patzek, T and Pimentel, D. Thermodynamics of Energy Production from Biomass. Critical Rev in Plant Sci 2005;24(5-6):327-364.

[140]. Irfan Afzal Mirza, Sana Ahmed and M. Shahid Khalil; Renewable Energy in Pakistan: Opportunities and challenges. A Sci J of Comsats - Science Vision 2011;(16-17).

[141] Mirza K, Ahmad N, Harijan K and Majeed T. Identifying and addressing barriers to renewable energy development in Pakistan. Renew Sustain Energy Rev 2009;13:927-31.

[142]. Asif A. Shah, S.M. Qureshi, Arabella Bhutto and Ambreen Shah. Sustainable development through renewable energy-The fundamental policy dilemmas of Pakistan Renew Sustain Energy Rev 2011;15:861-865.

[143]. Nidhal Abdulaziz and Mohammad Faisal Aziz. Prospects and Challenges of Renewable Energy in Pakistan 2010 IEEE International Energy Conference.

[144]. Syeda Shaima Meryem, Sheikh Saeed Ahmad and Neelam Aziz. Evaluation of biomass potential for renewable energy in Pakistan using LEAP model. Int J Emerg Trends in Eng and Develop 2013;3(1).

[145]. FBS, Pakistan statistical year book-2002: Federal Bureue of statistics (FBS), Government of Pakistan March 2002.

[146]. Hassan M.U, 2002 Biogas Technology to light up villages in Pakistan: Karachi Dawn science-dot-com magazine 2002;(14):6-7.

[147]. APEC (Asia- Pacific Economic cooperation) Energy Outlook for Asia and the Pacific. (C) 2013 Asian Development Bank.

[148]. Ashraf CM, Raza R and Hayat SA. Renewable energy technologies in Pakistan: Prospects and challenges. Renew Sustain Energy Rev 2009;13.6:1657-1662.

[149]. S. Ahmed, A. Mahmood, A.Hasan, G.Ahmad, S. Sidhu and M. Fasih Uddin Butt. A comparative review of China, India and Pakistan renewable energy sectors and sharing opportunities. Renew Sustain Energy Rev 2016;57:216-225.

[150]. Zuberi MJS, Hasany SZ, Tariq MA and Farrioglu M. Assessment of biomass energy resources potential in Pakistan for power generation. IEEE fourth international conference on power engineering, energy and electrical drives (POWERENG). Istanbul 2013;1301-1306.

[151]. Muhammad Naqvi, Jinyue Yan, Erik Dahlquist. Synthetic natural gas (SNG) production at pulp mills from a circulating fluidized bed black liquor gasification process with direct causticization. 23rd International Conference on Efficiency, Cost, Optimization, Simulation, and Environmental Impact of Energy Systems, ECOS 2010. Lausanne, Switzerland.Volume 2: Pages 83-91. 
[152]. Dr. Ehsan Ali and Ms. Nafeesa Irshad. Center for Advanced Studies in Energy at NUST (CAS-EN). Final Report : Survey on the Availability of Biomass in Punjab Pakistan Resource Mapping Study by IFC-World Bank Group 2015.

[153]. Chaudhry MA, Raza R and Hayat SA. Renewable energy technologies in Pakistan: prospects and challenges. Renew Sustain Energy Rev 2009;13:1657-62. 


\title{
A Review on Potential of Biomass based Bioenergy in Pakistan based on Present case and Future Perspectives
}

\begin{abstract}
Future energy security and environmental issues are major driving forces for increased biomass utilization globally and especially in developing countries like Pakistan. For efficient utilization of indigenous biomass resources in the future energy mix, it is important to gain knowledge of current energy system in various sectors. Some of the technologies and initiatives are under development to achieve transition from non-renewable resources to renewable resources, and reducing fossil fuel dependency and greenhouse gas emissions. Recently, number of proposals has been presented for the development of sustainable biofuels production methods for promise for accelerating a shift away from an unsustainable approach to possible sustainable production practices or a sustainable social, economic and environment. This article presents an extensive literature review of the biomass-based renewable energy potential in Pakistan based on current energy scenario and future perspectives. It also highlights the availability of the indigenous and local biomass resources and potential biomass conversion technologies to convert such resources to bioenergy. The drivers for utilization of indigenous biomass resources in future energy mix and challenges regarding awareness among stakeholders and R\&D to fill knowledge gaps are economically restraints. The article concludes with suggestions on future directions and policies for effective implementation of biomass based renewable energy production.
\end{abstract}

Keywords: future energy mix, gasification, agriculture residues, waste, biofuels

\section{Introduction}

The world's energy primarily depends upon fossil fuels and consumption is expected to increase rapidly. It will cause depletion of non-renewable fossil fuel resources, global warming and future energy security. Numerous technologies and initiatives are under way to partially replace nonrenewable resources with renewable resources and reducing fossil fuel dependency and greenhouse gas emission. Bioenergy cannot play a vital role to replace petroleum-based products with renewable alternatives, but it can also provide additional energy. The energy shortages in the form of electricity and gas have a direct impact on basic utilities as well as on the industrial economy [3]. In Pakistan, the cost of fossil fuel is one of the primary reasons for the energy crisis, since the domestic consumers and the local power industry utilized natural gas and furnace oil to generate heat and electricity [4]. To address such issues in the developing countries like Pakistan, biomass is considered as a potential resource. It is abundantly available in considerable quantities within the country. The renewable energy sources are interesting due to their low environmental impacts and providing the eco-efficient solution for developing and developed countries. European Union (EU) is generating approximately $71 \%$ of electricity from the renewable energy sources $[5,6]$. 
Biomass as a flexible resource of renewable energy can play a vital role to meet the global demand profiles in energy sectors like electricity, buildings and transport. Among renewable energy, biomass is one the largest energy source that represents $14 \%$ out of $18 \%$ renewable energy in global energy mix [7]. Currently, biomass represents about 10\% (50 EJ) of global total primary supply of energy and contributed $370 \mathrm{TWh}$ of electricity production in 2012 [8]. It is interesting to note that the final product from biomass conversion varies significantly based on different regions, i.e. wood fuel and charcoal for domestic heating and fuel in small scale industries in Asia and Africa, various liquid biofuels in Americas, and polygeneration of biofuels, heat and power production in Europe. The regions with large biomass resource availability also have substantial share of bioenergy reflecting in their total energy mix. Based on World's biomass energy data, Figure 1 shows the distribution of different biomass resources as global primary energy supply. According to IEA, biofuels have potential to meet about $27 \%$ of global transportation fuel requirement by 2050 that shows biofuels have considerably large potential to be expanded for future sustainability. The electricity generation accounts for $1.5 \%$ of global electricity production. Figure 2 shows biomass-based electric power generation in different regions from 2014 to 2016 and also forecast production till 2020 [9].

The developed countries are utilizing waste streams in the energy system as feedstock for a renewable energy production. However, the developing countries like Pakistan are still lagging behind the right methodology and execution of biomass as an alternative renewable energy resource. Currently, about $18 \%$ of the global total energy consumption comes from the renewable energy resources including biomass, hydro power, wind and solar energy [10]. Pakistan is one of the countries that is experiencing a severe energy crisis leading to adverse social and long term economic problems [11-13]. However, the country is focusing to utilize available indigenous sources, like biomass, solar, wind energy and hydro-power potential in order to meet the growing energy demands. According to Economic Year Book of Pakistan 2010-2016, the percentage consumption of energy (annually) from various resources e.g. oil, gas, coal, hydro and nuclear is depicted in Figure 3 [14].

Energy consumption is increasing steadily with increasing population in Pakistan. Previously Pakistan was utilizing local energy sources and later to overcome the energy shortage oil was imported for commercial industries [15] but still, energy needs are not fulfilled. Pakistan will have to endeavour for the alternative energy survival due to increased dependence on imported oil, electricity and liquefied petroleum gas (LPG) which has been shown in Figure 3 as annual consumption growth rate with variable ratios for oil, gas, LPG, coal, wind electricity, nuclear and hydral electricity respectively. In Pakistan, more than $60 \%$ of the population economy is related with agriculture and about $62 \%$ population living in rural areas depends on traditional biomass as a primarily source for cooking and space heating at the household level [13,16-22]. In rural areas of Pakistan wood and animal waste are major biomass sources for energy needs [23]. Modern biomass or liquid biofuels (such as ethanol and biodiesel) used mostly for transportation 
and for generation of electricity are emerging energy alternatives in developing industries. Rural population in Pakistan has limited access to fossil fuel based energy resources and people rely on traditional methods of using wood, animal dung and crop waste for domestic fuel [24]. Renewable energy is expected to play a crucial role in Pakistan's future energy-demands [25]. Modern bio-energy technologies are crucial for Pakistan to utilize the available agricultural residue as renewable resource which may serve a supplementary role in completing the energy demands of the country.

\section{Indigenous biomass resources}

The organic matter in the form of crops residue, wood and animal wastes had stored solar energy in it by photosynthesis process [27-31]. Human beings are using biomass as a source of energy in the form of wood for heating homes and to cook food. In Pakistan like other countries, biomass plays an important role in rural economy as replacement to fossil fuels as the primary energy source. However, for commercial activities, there should be a significant potential source of energy [32]. Biomass is the $4^{\text {th }}$ largest source of energy and provides almost $10 \%$ of the global primary energy supplies, and could be in solid, liquid or gaseous form. Figure 4 shows a comparison of electricity generation from biomass in Pakistan during 2015 to the biomass based electricity generation worldwide [37]. Biomass used for energy production, primarily composed of cellulose, hemicellulose and lignin

Due to unawareness and lack of government policies for biomass utilization, huge amount of crops residues are burnt as waste instead to utilize it for production of energy. Biomass in Pakistan is generated from several sources including agriculture crops, forest residues, industrial waste and municipal solid wastes [34-36]. Different types of biomass resources (Figure 5) include [38-41];

- Agricultural residues such as cane trash, bagasse, straws and green agricultural wastes

- Food processing wastes

- Wood from natural forests and woodlands

- Forestry residues

- Industrial wastes, such as black liquor from paper manufacturing

- Sewage

- Agro-industrial wastes, such as sugarcane bagasse and rice husk

- Animal Livestock

- Municipal solid wastes (MSW)

This review will discuss only those sources which are abundantly available in Pakistan for bioenergy production. Potential sources of biomass, its current utilization and technologies for effective utilization for production of energy are listed in Table 1.

Biomass forms solid liquid and gaseous fuels by going through chemical biological as well as physical processes. The aim is to convert the bulky, carbonaceous low energy content waste to a 
fuel. Among the energy resources biomass ranks fourth providing 35\% of the energy mostly in developing countries. Biomass is a sustainable, environment friendly source of fuel. It absorbs carbon dioxide during growing stages and during combustion emits it. Thus, carbon dioxide is recycled and do not add to greenhouse effect. In addition, biomass can be cultivated as energetic crops to be consumed directly without indulging a middle man to supply raw materials

\subsection{Agriculture crops Waste}

Pakistan being an agrarian economy produces tons of farms residue which are potential biomass feedstock for energy conversion. An agricultural residue produces as a by-product from harvesting and processing of a number of crops mainly wheat straw, rice straw, rice husk, cane trash, bagasse and cotton sticks [42]. In Pakistan 26,280,000 hectares' land is under cultivation according to World Bank statistics [40], supporting economy of $62 \%$ of peoples who live in rural area [44]. Most of the crops residue is directly utilized by the people in the countryside for their basic need of energy for cooking.

Pakistan is the $4^{\text {th }}$ major producer of sugar from sugarcane [45], where it is grown on large scale and generates a huge quantity of cane trash during harvesting season along with bagasse production during sugar manufacturing. In year of 2010-11, approximately 63,920,000 metric tons of sugarcane was harvested and trash generation of around 5,752,800 metric tons is recorded which has potential to generate around $9,475 \mathrm{GWh}$ per year as bioenergy [46]. Under the Government of Pakistan regulations, sugar mills are allowed to produce electric power up to $2000 \mathrm{MW}$ from bagasse as fuel for running of sugar mills [47].

Besides cane trash and bagasse cotton sticks form cotton crop is another potential source for production of bio-energy in Pakistan. In order to meet the demand of local and international textile industry, approximately $11 \%$ of total land cultivation area is reserved for cotton production. Approximately 1,474,693 metric tons of cotton sticks residue was reported in year $2011[48]$.

\subsection{Forest wood residues}

For the time being people rely on wood for cooking and heating their homes. People collect woody sticks and save them to be utilized for burning in cooking stoves [55]. People in northern areas of Pakistan till now rely on wood from forest for cooking and heating purposes. Forest residue comprises the small branches, trees, tops and unused wood left behind after cutting and cleaning of forests. Out of total available land, 5.2\% is covered with forest, which is about 4.224 million hectares' area [56].

Forest residue, a biomass source is environmentally beneficial and can provide significant amount of total bioenergy which is almost $80 \%$ of the total energy consumption in Pakistan from biomass resources [57]. 


\subsection{Animal Waste}

Besides agriculture crops residue animal waste is also used as energy source for burning or cooking purpose. The animal waste is generally termed as manure and contains organic matter which on further processing can be directly converted into biogas. According to the literature survey in Pakistan, approximately 368,434,650 metric tons of manure is generated annually [58]. In many rural areas of Pakistan, small scale anaerobic digestions are used to convert animal manure to biogas for household and small industries. In urban areas of the Pakistan many cattle farms are producing a huge amount of manure which is used as fertilizer in the agriculture sector for soil fertility [59-60].

\subsection{Municipal Solid Waste}

Pakistan is among those countries which are facing the problem of environmental concerns regarding the health issues due to mishandling of municipal solid waste (MSW). MSW comprises the organic matter as well the inorganic metals and can be processed through various methods to utilize for energy generation. According to literature survey Pakistan, MSW with a calorific value of about $6.89 \mathrm{MJ} / \mathrm{Kg}$ per annum [61] which can be processed for power generation in capacity around 13,900GWh annually. In Pakistan major cities like Islamabad, Lahore, Karachi and Multan have industries parks, where huge amount of MSW is produced having a great potential for power generation [62]. MSW includes the industrial wastes as well as commercial and household wastes. However, this potential source of power generation is wasted due to unawareness in proper collection and becoming a source for different diseases instead of an opportunity.

\section{Biomass conversion technologies}

Biomass wastes are effectively converted into bioenergy and biofuels by using various biochemical and thermal technologies including anaerobic digestion, gasification and pyrolysis shown in Figure 6. It is an efficient way to manage the waste material and convert it into a valuable product. Biomass can be utilized for electricity generation and production of valuable chemicals using Fischer-Tropsch reaction. Biomass in the form of MSW is getting recognition worldwide as a potential source for energy generation. Moreover, integration of biomass conversion $t$ bioenergy is an effective way of waste management for environment protection.

\subsection{Thermal conversion technologies}

During thermal conversion processing, biomass feedstock is processed to bioenergy by heating on different temperatures yielding solid, liquid fuels and gases. These decomposition processes take place both on small scale and large scale and provides sufficient bioenergy to overcome the power requirements. 


\subsubsection{Pyrolysis}

Chemical composition of biomass like cellulose hemicellulose and lignin determines the pyrolytic properties. They go through a series of reactions to produce a variety of different products. The distribution of products depends on the reaction conditions. Biomass and waste material adds up to $10 \%$ of the total energy supply of the world. [54]. At temperature below 300 ${ }^{\circ} \mathrm{C}$, pyrolysis of cellulose decreases the molecular weight, water generation, formation of carbon dioxide, carbon monoxide and char. At temperature between 300 to $500{ }^{\circ} \mathrm{C}$, depolymerization of molecules to anhydrous glucose occur that finally converted to tarry pyrozylate. At even higher temperatures the anhydrous sugar go through fission, dehydration, disproportionation and decarboxylation reactions giving volatile and light weight gases and other products. The agricultural waste and organic waste are common raw materials for pyrolysis in Asian countries [63-67].

Biomass feedstock undergoes thermal decomposition at high temperature of $500-800^{\circ} \mathrm{C}$ in absence of oxygen yields biogas, liquid (biofuels) and solid (char) products [68]. The amount of yielding products depends upon temperature. Low temperature yields solid medium favours liquid while high temperature yield the biogas [69]. Literature survey on pyrolysis provides information that $40-75 \%$ of its major products is biofuel [70-73].

\subsubsection{Combustion}

During combustion, biomass feedstock is directly combusted at a very high temperature of 800$1000^{\circ} \mathrm{C}[74]$ and hot flue gases are utilized to produce steam for electricity generation using turbines [50]. Biomass combustion is not only the oldest form of combustion used by humanity, but it is also one of the most complex combustion systems to manage since it involves the use of solid fuels in a multi-phase reaction system with extensive interaction between the thermal and mass fluxes, processes that have only recently been properly analysed and used in simulations to design efficient combustion systems.

\subsubsection{Gasification}

Biomass decomposed to gaseous form through a process called gasification. In this process biomass undergoes through thermal decomposition by incomplete combustion into combustible gas mixture (comprises hydrogen, methane, carbon dioxide, carbon monoxide, nitrogen and some water vapours) [76]. By gasification very low yield of gas is produced and utilized on house fuel engines and in laboratory for different chemical transformations [77, 154].

Gasification is similar to pyrolysis but carried out at high temperatures to control the gas production [50]. The gases formed are known as producer gas and are a mixture of methane hydrogen carbon monoxide nitrogen and carbon dioxide. Biomass gasification is recently introduced to enhance the efficiency of the process and reduce input cost with the help of gas 
turbine technology. Up to $50 \%$ of efficiency can be achieved by combined-cycle gas turbine systems. Here waste gases are recycled to produce steam for use in a steam turbine.

\subsection{Biochemical Decomposition}

The organic matter in biomass is decomposed by the microorganism in presence or absence of oxygen to generate biogas (Eq. 1). Microorganisms can efficiently breakdown the chemical structure of organic matter and convert it into biogas as a simple chemical conversion.

$$
\mathrm{C}_{6} \mathrm{H}_{12} \mathrm{O}_{6} \longrightarrow 3 \mathrm{CO}_{2}+3 \mathrm{CH}_{4} \quad-\cdots-- \text { Eq. } 1
$$

In recent decades, much research has been done in Pakistan by utilizing vast amounts of agricultural lignocellulosic biomass and animal manure and its potential conversion into different high value products including bio-fuels, value added fine chemicals and cheap energy sources for microbial fermentation and enzyme production [78-79].

\subsubsection{Anaerobic digestion}

Biogas is generated from biomass feedstock in the absences of oxygen with the help of microbial activity. Both on domestic and industrial level biomass waste are processed to convert it in valuable biogas which is a mixture of methane, hydrogen, carbon dioxide and traces of other gases. A typical digester is used to digest the biomass by microorganism and to convert it in biogas which can be directly used for cooking as well as in gas engines on industrial scale [8081].

\subsubsection{Fermentation}

Fermentation is a biochemical process that involves hydrolysis of sugars by the activity of microorganisms especially bacteria into ethanol and the process is termed as fermentation. In various countries of the world, fermentation is carried out on an industrial scale for the production of bioethanol in very high yields. Biomass feedstock used in this process is majorly sugar and starch crops, as $60-70 \%$ corn starch used globally for ethanol production [82]. However, use of lignocellulosic biomass is desired to avoid the fuel vs. food competition.

\subsubsection{Transesterification}

Biodiesel is produced through catalytic transesterification of bio-oil. Variety of vegetable oil feedstock including rapeseeds, soya bean, mustard, sunflower, hemp and palm oil as well animal fat is utilized for the production of biodiesel on an industrial scale [83]. During the reaction, catalyst may be an acid, base or an enzyme which is immobilized on a substrate to increase the rate of reaction.

\section{Drivers and significance of biofuels}

We are living in era of technology, where energy is the main driver in the development of countries. Due to growing population and urbanization, energy demand becomes more than production. This deficit in energy cannot be covered by only relying on fossil fuels reservoirs. 
Thus, new energy sources need to be discovered and utilized in order to overcome the energy crisis.

Pakistan is also facing the energy crisis due to depletion of energy reservoirs and increasing energy demand. So, there is need for alternative energy sources. Concept of bioenergy from biomass become reality in different countries around the world (Table 2) to fulfil the increasing demand of energy due to some of its specific properties [84-85];

- Reducing greenhouse gas emission

- Widely available source and flexible in application

- Rural economy diversification

- Reduce land degradation

- Accessible energy

Pakistan and its neighbouring countries have focused on utilization of biomass for bioenergy with supporting research in this field (Table 3). Bioenergy from biomass not only provides energy to compete for the energy demands but also help in handling the waste of industries, commercial and household in a proper way. Effective management of waste is essential to reduce spread of diseases and other environmental related issues [86].

Concept of bioenergy from biomass not only provides energy but it also helps to diversify the economy of a country and support and developed new industries in developing countries. Utilization of biomass for bioenergy is expected to strengthen the agricultural economy as well [87].

\subsection{Biogas}

Anaerobic bacteria decompose the waste organic matter to convert it into biogas. Biogas comprises of methane (majorly), carbon dioxide and traces of other gases. Biogas formed during anaerobic digestion is respiratory product of decomposers, but being combustible it can be utilized as energy source [106]. It is naturally produced in rice paddies, swamps and in the sediments of lakes and oceans where anaerobic digestion takes place. It can also be produced in animal manure when remains in wet condition. In Pakistan's rural areas, where large amount of crops residue and cattle waste is available, have potential to produce biogas on small scale [107]. Small biogas plants are introduced there for household activities; also on small industries, it could provide enough energy to run them easily.

Literature survey reveals that 5357 biogas plants are installed and working in the whole country and have the potential of biogas production about 12-16 million $\mathrm{m}^{3} /$ day that can support the population living in rural areas for cooking purpose [108-109].

\subsection{Transport fuels}


Besides the industrial needs for energy, transportation sector is highly dependent on energy from liquid fossil fuels and transportation is the main consumer of petro-fuels in Pakistan [110]. Biofuels are liquid fuels mostly synthesized from different oils extracted from number of plants and from the crops residues processed as waste through strategic methods [111]. A number of biofuels are synthesized worldwide including biodiesel, bioethanol, gasoline, butanol etc. But in Pakistan biodiesel and bioethanol is can act as an alternative to fossil fuel.

\subsection{Biodiesel}

It is the liquid fuel mainly a fatty acid alkyl ester produced from the processing of waste oil from household and from oil producing plants. Major plants which contribute for the production of biodiesel include corn, canola, soya bean, peanut sunflower, mustard seeds and avocado. Recycling of cooking oil and animal fats also yields biodiesel [112].

About $70 \%$ of Pakistan's overall geographical area lay coarse, thus providing an opportunity to cultivate inedible oil-yielding vegetation that in turn is converted to biodiesel. Thus, it is necessary to develop plant-based biodiesel productions in Pakistan, which will be valuable for the improving socio-economic settings of the country. To use biodiesel as substitute energy source in Pakistan, the AEDB has verbalized policy recommendations, the primary aims of which are to minimize the bill of imported fuel of the country, address the demand of raw material for biodiesel which will be the prime goods for biodiesel fabrication, and promote a pollution-free environment. Also on 14th Feb. 2008, the Economic Coordination Committee (ECC) of the National Cabinet has permitted the strategy for the use of biodiesel as an alternate energy source in its conference. Striking points of the dogma are as follows:

1. AEDB shall be the primary coordinating and facilitating body for the National Biodiesel Program.

2. Gradual introduction of biodiesel fuel blends with petroleum diesel so as to achieve a minimum share of $5 \%$ by volume of the total diesel consumption in the country by the year 2015 and $10 \%$ by 2025 .

3. The Ministry of Petroleum \& Natural Resources shall come up with the fuel quality standards for B-100 and blends up to B-20.

4. Oil Marketing Companies (OMCs) are to purchase biodiesel (B-100) from biodiesel manufactures; and sell this biodiesel blended with petroleum diesel (starting with B-5) at their points of sale

Esterification of fatty acids plants oil and animal fats in the presence of alcohol and catalyst yield biodiesel used in replacement of petro fuels in transportation [113-116]. Biodiesel favours the transportation over petrofuels due to following benefits [82];

- Eco-friendly 
- Can be utilized in any diesel engine without any modification

- Contains no petroleum, but can be blended with conventional diesel engines

- Clean burning alternative fuel

- Degradable, non-toxic and free from sulphur \& lead

\subsection{Bioethanol}

Fermentation of waste residue using bacteria/Yeast can produce bioethanol which is a valuable alternative to gasoline for internal combustion engines [117,126]. Biomass has significant potential for bioethanol production including the crops residues and municipal solid waste [118]. Literature survey reveals number of methods reported for bioethanol production worldwide in recent decades [119-124], where bioethanol proves to be the best fuel for internal combustion engine. Currently, bioethanol is produced on large scale on a large from sugar-containing raw materials including sugarcane and starch based crops [125].

\section{Potential Impact of bioenergy on various sectors}

\subsection{Bioenergy impacts on households}

In Pakistan, around $62 \%$ population is living in rural areas, where people fulfil their energy demand by relying on traditional fuels like firewood, animal dung and crops residue for household cooking and heating purposes [127]. Biogas energy has a good prospect in rural areas as well in urban areas as an efficient fuel for cooking stoves Whereas, dung-waste has also the potential to produce approximately 12 million $\mathrm{m}^{3} /$ day of biogas which can provide average energy of 28 million people of rural areas [128]. Besides private sector, almost 4137 biogas units were installed by Directorate General of New and Renewable Resources (DGNRER) under Ministry of Petroleum and Natural Resources throughout the country by a scheme. These units have the potential to provide 3000 and 5000 cubic feet of biogas per day for heating and lighting purposes [129]. 76\% household in Pakistan depends on biomass resources due to unavailability of other energy alternatives [130]. As total biomass energy consumption in Pakistan was estimated to be 954.56 PJ by the year 2010, where 711.75 PJ (76\%) is consumed by the household sector.

\subsection{Bioenergy impacts on industrial sector}

On industrial scale, petroleum products are primary fuels for running the industries, wherever the introduction of bioenergy from biomass as a new source of energy is now focused as an energy alternative. In Pakistan about 23\% (209.34PJ) of the total energy consumption is reserved for industrial sector [131]. Pakistan is ranked at $10^{\text {th }}$ number in list of countries using biomass as energy source in industries (Table 4). The primary biomass source for industrial scale is bagasse from sugarcane which can be used by many industries as energy source directly or indirectly. About $70 \%$ of the total bagasse is directly used as fuel for condensation-extraction steam turbines (CEST) in sugar industry itself while remaining is utilized indirectly in different 
industries as fuel for combined heat and power ( $\mathrm{CPH})$ generation system [132]. Moreover, agricultural residues like rice husk, wheat, corn stalks and cotton sticks etc. contributes about 85.5PJ biomass energy for the industrial sector. But most of the crops residues are directly used as burning fuel in bricks kilns [133].

\section{Benefits of bioenergy over fossil fuels for Pakistan Economy}

Urbanization and developments in industrial sector and structures led to environmental problems. Petroleum products are the major energy source in almost every industry as well as primary fuel for transportation. Presence of volatile organic compounds (VOC) cause emission of harmful greenhouse gases (GHG), thus contributing seriously in environmental problems [138]. A long-term solution to these problems is required for a sustainable development. In this regard, renewable energy is emerging as efficient and effective solution for environmental issues [136]. Bioenergy from biomass is getting the attention in recent years. Bioenergy has numerous benefits for environment as follow [137];

- Reducing GHG emissions

- Renewable or biodegradable energy

- Providing economic development as well employment opportunities

- Supporting food- processing and agriculture industries

- Cost saving and abundantly available

- Reduce landfills

- Energy reliability and security

- Reduce dependence on fossil fuels

- Can be used to create different products (i.e. ethanol)

\section{Exploitation of bioenergy in Pakistan}

Biomass will be a significant source of alternative energy in future. In order to achieve sustainable development in bioenergy, many challenges are there to face and resolve as enlisted in Table 5 [138-139]. Taking the hurdles under consideration biomass utilization for bio-energy production, couples of things are required special attentions.

Awareness on different sectors: There is a need to highlight those success stories of biomass utilization for energy in urban and rural areas, which can be replicated [140]. It will be the most critical and crucial step towards making sustainable bioenergy program successful. Public organizations and media should be actively involved to provide necessary information and general awareness regarding the impacts of bioenergy from biomass through specialized agencies and training facilities. Farmers must be encouraged to adopt the biomass based bioenergy technologies for sustainable agriculture. 
Science and technology $(S \& T)$ developments: Science and technology centres for bioenergy and clubs should be launched for the promotion of S\&T in all educational institutes as well the establishment of museum and display centre for science and technology. Mirza et al. [141] pointed out flaws by suggesting that the community participation is only restricted to just a few demonstrated projects, which resulted in a lack of coordination among departments/institutions responsible for renewable energy development and commercialization. Technical education infrastructure should be efficiently utilized to promote the concept of sustainable development through the introduction of courses dealing with renewable energy technologies. Trained S\&T policy making professionals are needed to be involved in policy making process at all levels [142].

Research and development $(\boldsymbol{R} \& D)$ : There is need for focused research and development (R\&D) to play a vital role in the development of sustainable bioenergy so that the cost can be reduced and the technology is made affordable for the poor households. The professional educational institutes and universities have to play a very important role to accept the challenge and to introduce the subject of renewable energy and other emerging technologies as course in different degree programs. Biomass potential for bioenergy should be considered as capacity issues in govt. and public sector institutions, private sector and also among financial institutions [143].

\section{Promotional strategies of biomass for energy}

Besides conventional sources for bioenergy, there is a need to find other resources to overcome the demand and supply issue of energy. Pakistan is enriched with number of easily available biomass resources which can be utilized in good way to generate energy. In recent studies, Longrange Energy Alternative Planning system (LEAP) model was used to track production and consumption of non-woody crops and livestock Table (crops and animals) waste biomass in Pakistan and its perspective as renewable energy in coming future, where yield of bagasse rises up to 152.2 trillion with greatest share comparatively in the category of major crops as shown in Table 6 [144]. Here are some suggestions to utilize other alternative biomass available in Pakistan;

City wastes: In Pakistan, urban areas are producing around of 55,000 tons of solid waste on daily basis, which if collected and processed properly can be utilized for energy production. A huge amount of waste is burnt on open land which causes emission of GHG and creating the environmental pollution as well as spreading different diseases. If this waste is burnt properly then its heating energy can be utilized for production of electricity. Through proper landfill techniques and managing solid wastes a reasonable amount of heat and electric power can be generated. 
Poultry Litter: Poultry-based farms have broad industrial networking in Pakistan. A huge amount of poultry litter especially chicken litter both from layer-chicken and broiler-chicken generated on daily basis. With special attention, such source can be utilized for bioenergy production. It is estimated that 15.0 million layer-chicken and 528 million broiler-chicken are expected to be produce between 2003-2004 year including share of $68 \%, 22 \%, 6.5 \%$ and $3.5 \%$ of Punjab, Sindh, KPK and Baluchistan respectively. Literature survey reveals that 15 tons per year chicken-litter is scraped out from a shed of 3000 chicken-birds from poultry farms in Pakistan. If this waste-litter processed in a technical way can provide enough energy required for generation of $40 \mathrm{MW}$ of electricity on daily basis.

Animal slurry: According to livestock census of 2000, and Federal Bureau of Statistics (FBS) [145] of Pakistan, there are 46.69 million of animals including buffaloes, cows and bullocks producing 700 million $\mathrm{Kg}$ dung per day. Hassan et al [146] estimated that besides 50 million $\mathrm{Kg}$ of bio-fertilizers, 17.5 million $\mathrm{M}^{3}$ biogas can be produced through bio-methanation from animal dung per day. As till now biogas from animal dung is produced at local levels but it can take up to commercial basis if government makes some policies against it.

\section{Future directions}

In Pakistan biomass will be a significant alternative energy source in future. In order to overcome the energy shortage researcher and scientist are now focusing more on biomass for bioenergy production due to its availability for energy generation [147-148]. The Government of Pakistan in collaboration with different countries has made new policies and projects on bioenergy production from biomass [149] that are under progress in different universities, Govt. and privative organizations shown in Table 7. Here are some policies and projects are highlighted which are currently in progress;

> Pakistan has made a policy to add RSE (Renewable \& Sustainable Energy) for energy production; Alternative Energy Development Board (AEDB) has been established to contribute $5 \%$ energy production from renewables. AEDB is now working on energy production project by using huge resource of biogas near Karachi in Landhi cattle colony to produce $30 \mathrm{MW}$ which is being funded by New Zealand.

$>$ A letter of intent was issued for $12 \mathrm{MW}$ power plant established for utilization of agricultural wastes in Jhang and 9 MW plant is going to be installed at Pak Ethanol Pvt. Ltd., Sindh.

$>$ In coming years 5000 biogas units will be installed all over the country by Pakistan Counsel of Renewable Energy Technologies (PCRET). 
Government has invested 356 million to import 1400 biogas plants [150].

Biomass/ Waste-to-Energy Following Biomass/Waste-to-Energy projects are in various stages of implementation under IPP mode:

- M/s SSJD (12 MW) Sindh

- M/s Lumen Energia (12 MW Shahkot)

- Punjab M/s Biomass Power Generation Limited (12 MW), Faisalabad M/s Green Sure Environmental Solutions (12 MW), Mardan, KPK

> Also, framework for power Co-generation 2013 (Biomass/Bagasse) was approved by Economic Coordination Committee (ECC) for bagasse/biomass based sugar industry projects. 1500-2000 MW of power is expected to be generated in next 2-3 years [151].

$>$ Centre for Advanced Studies in Energy at NUST (CAS-EN) is working on project entitled; "Biomass Resource Availability Study" funded by International Finance Corporation a subsidiary of World Bank Group (IFC-WBG) [152].

\section{Conclusions}

Biomass is an emerging renewable resource for bioenergy production to meet the future energy demand in the developing countries. Pakistan as a developing country also needed to put forth its efforts for potential production of bioenergy from biomass to tackle the energy crises. This article highlights the importance of bioenergy production from biomass and areas for more attention on development of infrastructure for biomass conversion to bioenergy, research works and its availability on all scales. Considering the importance of bioenergy from biomass some technological steps has been taken by the govt. However, govt. and private sectors are required to act on emergency basis for producing more bioenergy to cut the energy deficit in the country. In addition, the article has a lot of significance for Pakistan's rural areas where considerable amount of biomass resource in the form of indigenous agricultural wastes is available. It is important to identify suitable thermal or bio-chemical conversion techniques for different biomass producing flexible fuels like char, pyrolysis vapours, bio-oil or synthesis gas which could be further converted to methane, dimethyl ether (DME), methanol, hydrogen etc. The flexible fuels may then be utilized for combined heat and power production or converting them to vehicle fuels. This article will provide base for future evaluation of potential biofuel, electricity or thermal energy production at distributed small scale that may be sufficient to meet energy requirement in the developing countries globally.

\section{Acknowledgment}


Authors have no conflict of interest and would like to acknowledge the National University of Sciences \& Technology (NUST), Pakistan.

\section{References}

[1]. Eugene D. Coyle and Richard A. Simmons. Understanding the Global Energy Crisis. Purdue University Press e-books 2014.

[2]. Holdren JP. Population and the Energy Problem, Population and Environment. 1991;231-55.

[3]. S. Amin. Solution for energy crisis in Pakistan. IPRI Publications 2013.

[4]. M. Asif. Sustainable energy options for Pakistan. Renew Sustain Energy Rev 2009; 13:903-909.

[5]. Cunado J. and Gracia FP. Oil prices, economic activity and inflation: Evidence for some Asian countries. Q Rev Econ Financ 2005;45(1):65-83.

[6]. Global status report. REN21. Renewable Energy Policy Network for the $21^{\text {st }}$ Century; 2012. Available at: http://www.map.ren21.net/GSR/ GSR2012.pdf.

[7]. World Energy Council report, 2016. World Energy Resources Bioenergy (2016). https://www.worldenergy.org/wpcontent/uploads/2017/03/WEResources_Bioenergy_2016.pdf

[8]. International Energy Agency (IEA) statistics book, 2016. Renewables Information 2016 EDITION. ISBN PRINT 978-92-64-25866-2 / PDF 978-92-64-25867-9

[9]. International Energy Agency, 2015. Medium-Term Renewable Energy Market Report 2015, OECD/IEA, Paris.

[10]. Kumar A, Kumar K, Kaushik N, Sharma S and Mishra S. Renewable energy in India: current status and future potentials. Renew Sustain Energy Rev 2010;14(8):2434e42

[11]. PC. Pakistan in the 21st century: Vision 2030. Planning Commission, Government of Pakistan 2007.

[12]. A. W. Bhutto, A. A. Bazmi and G. Zahedi. Greener energy: Issues and challenges for Pakistan-Biomass energy prospective. Renew Sustain Energy Rev 2011; 15:3207-3219.

[13]. Economic survey of Pakistan, Islamabad. Government of Pakistan Ministry of Finance 2010 . 
[14]. Pakistan Year Book 2015. Government of Pakistan Ministry of Finance, Economic Affairs, Revenue, Statistics and Privatization, Islamabad. Available at: www.pbs.gov.pk.

[15]. A. Arshad, M. Zakaria and Xi Junyang., Energy prices and economic growth in Pakistan: A macro-econometric analysis. Renew Sustain Energy Rev 2016; 55:25-33

[16]. Sahir MH and Qureshi AH. Assessment of new and renewable energy resources potential and identification of barriers to their significant utilization in Pakistan. Renew Sustain Energy Rev 2008; 12:290-298.

[17]. Malik A. How Pakistan is coping with the challenge of high oil prices. Pak Dev Rev 2007;46(4):551-75.

[18]. Usama Perwez, Ahmed Sohail, Syed Fahad Hassan and Usman Zia. The long-term forecast of Pakistan's electricity supply and demand: An application of long range energy alternatives planning. Energy 2015;93:2423-2435

[19]. Pakistan Year Book 2013. Government of Pakistan Ministry of Finance, Economic Affairs, Revenue, Statistics and Privatization, Islamabad. Available at: www.pbs.gov.pk.

[20]. Dr. Zafar Fatmi, Dr. M. Masood Kadir, Dr. Waqar Ahmed and Dr. Ambreen Kazi. Situation Analysis of Household Energy Use and Indoor Air Pollution in Pakistan. Department of Child and Adolescent Health and Development WHO 2005.

[21]. Saad Butt, Ingo Hartmann and Volker Lenz. Bioenergy potential and consumption in Pakistan. Biomass Bioenergy Rev 2013;58:379-389.

[22]. Inayatullah Jan. What makes people adopt improved cook stoves? Empirical evidence from rural North West Pakistan. Renew Sustain Energy Rev 2012; 16:3200-3205.

[23]. Mirza Umar K, Ahmad Nasir, Majeed Tariq and Harijan Khanji. Wind energy development in Pakistan. Renew Sustain Energy Rev 2007;11(9):2179-90.

[24]. Syed S. Amjid, Muhammad Q. Bilal, Muhammad S. Nazir and Altaf Hussain. Biogas: renewable energy resource for Pakistan. Renew Sustain Energy Rev 2011; 15:2833-2837.

[25]. M. Saif Ur Rehman, Naim Rashid, Ameena Saif, Tariq Mahmood and Jong-In Han. Potential of bioenergy production from industrial hemp (Cannabis sativa): Pakistan perspective. Renew Sustain Energy Rev 2013;18:154-164.

[26]. Perez MG, Chaala A and Roy C. Vacuum pyrolysis of sugarcane bagasse. J Anal Appl Pyrolysis 2002;65:111-136.

[27]. Demirbas A. Biomass resource fascilities and biomass conversion processing for fuels and chemicals. Energy Convers Manage 2001;42:1357-1378. 
[28]. McKendry P. Energy production from biomass (Part 1): Overview of biomass. Bioresource Technol 2002;83:37-46.

[29]. Shaheen Rafi Khan. Viewing Biofuel (Ethanol) Prospects in Pakistan through a Sustainable Development Prism. SDPI Research and News Bulletin 2007;14(3).

[30]. C. Baskar. Biomass Conversion. Springer-Verlag Berlin Heidelberg 2012.

[31]. Peter Quaak, Harrie Knoef and Hubert E. Stassen. Energy from Biomass: A Rev Combust and Gasific 1999;23:422.

[32]. A. Mahmood, N. Javaid, A. Zafar, R. Ali Riaz, S. Ahmed and S. Razzaq. Pakistan's overall energy potential assessment: comparison of LNG, TAPI and IPI gas projects. Renew Sustain Energy Rev 2014;31:182-193

[33]. Klass D. Biomass for renewable energy and fuels. Encyclopedia of energy. New York: Elsevier Inc 2004.

[34]. H.B. Goyal, Diptendu Seal and R.C. Saxena. Bio-fuels from thermochemical conversion of renewable resources: A review. Renew Sustain Energy Rev 2008;12:504-517

[35]. Bridgewater A. V. Principles and practice of biomass fast pyrolysis processes for liquids. J Anal Appl Pyrolysis 1999;51:3-22.

[36]. Peter McKendry. Energy production from biomass (part 1): Overview of biomass Bioresource Technol 2002;83:37-46

[37]. (OICCI): Overseas investors chamber of commerce \& investments Pakistan. Energy sub-committee NEPRA's State of Industry Report 2015.

[38]. L.S. Esteban and J.E. Carrasco. Biomass resources and costs: Assessment in different EU countries. Biomass Bioenergy 2011;35:21-30.

[39]. D. Alfonso, C. Perpiñá, A. Pérez-Navarro, E. Peñalvo, C. Vargas and R. Cárdenas. Methodology for optimization of distributed biomass resources, evaluation, management and final energy use. Biomass Bioenergy 2009;33(8):1070-1079.

[40]. Matti Parikka. Global biomass fuel resources. Biomass Bioenergy 2004;27(6):613-620

[41]. Suresh Chauhan. Biomass resources assessment for power generation: A case study from Haryana state, India. Biomass Bioenergy 2010;34(9):1300-1308.

[42]. J. Kumar Saini, R. Saini, and L. Tewari. Lignocellulosic agriculture wastes as biomass feedstocks for second-generation bioethanol production: Concepts and recent developments Biotech 2015;5(4):337-353. 
[43]. World Bank 2015. Pakistan Development Update Washington, DC. C World Bank. https://openknowledge.worldbank.org/handle/10986/22926 License: CC BY 3.0 IGO.

[44]. Government of Pakistan. Economic Survey of Pakistan, Islamabad. Ministry of Finance 2006.

[45]. M. Aamir Iqbal and Asif Iqbal. Sugarcane Production, Economics and Industry in Pakistan. American-Eurasian J. Agric. \& Environ. Sci 2014;14(12):1470-1477.

[46]. Annual report 2014 Pakistan sugar mills association 2014-15 available at: www.psmacentre.com

[47]. Sugar industry allowed to generate 2,000 MW electricity /http://www.jang.com.pk/thenews/nov2005-daily/ 29-11-2005/main/main13.html, accessed on 07 March 2007.

[48]. Pakistan Economic forum III. Draft report 2015. The Pakistan Business Council; available at: http://www.pbc.org.pk.

[49]. Bhattacharya SC, Abdul Salam P, Runqing H, Somashekar HI, Racelis DA and Rathnasiri P. G. An assessment of the potential for non-plantation biomass resources in selected Asian countries for 2010. Biomass Bioenergy 2005;29(3):153-166.

[50]. Zia Ud Din and A. Zainal Z. Biomass integrated gasification-SOFC systems: Technology overview. Renew Sustain Energy Rev 2016;1356-1376.

[51]. Elauria JC, Castro MLY, Elauria MM, Bhattacharya SC and Abdul Salam P. Assessment of sustainable energy potential of non-plantation biomass resources in the Philippines. Biomass Bioenergy 2005;29(3):191-198.

[52]. Zhongfu Tan, Kangting Chen and Pingkuo Liu. Possibilities and challenges of China's foresty biomass resources utilization. Renew Sustain Energy Rev 2015;368-378.

[53]. Tao, Khan, Strezov Vladimir and J Evans Tim. Lignocellulosic biomass pyrolysis: A review of product properties and effects of pyrolysis parameters. Renew Sustain Energy Rev 2016;1126-1140.

[54]. Frank Spellman Forest-Based Biomass Energy: Concepts and Applications. (C) 2012 Taylor and Francis Group LLC.

[55]. Danish M, Naqvi M, Farooq U, Naqvi S. Characterization of South Asian agricultural residues for potential utilization in 'Future energy mix'. ICAE 2015, Abu-dhabi.

[56]. G.o.P. Ministry of Finance. Economic Survey of Pakistan. Available: 〈http:// www.finance.gov.pk/survey/chapters_13/); 2012-2013. 
[57]. Sheikh MA. Renewable energy resource potential in Pakistan. Renew Sustain Energy Rev 2009;13:2696-2702.

[58]. Ravindranath NH, Somashekar HI, Nagaraja MS, Sudha P, Sangeetha G and Bhattacharya SC. Assessment of sustainable non-plantation biomass resources potential for energy in India. Biomass Bioenergy 2005;29:178-190.

[59]. Compendium on Environment Statistics of Pakistan 2010 Federal Bureau of Statistics Government of Pakistan. Available at: http://www.pbs.gov.pk/

[60]. Guerrero LA, Maas G and Hogland W. Solid waste management challenges for cities in developing countries. Waste Manag 2013;33:220-232.

[61]. J. Akhtar and N. Saidina Amin. A review on operating parameters for optimum liquid oil yield in biomass pyrolysis. Renew Sustain Energy Rev 2012;16(7):5101-5109

[62]. AV B. Principles and practice of biomass fast pyrolysis processes for liquids. J Ana Appl Pyrolysis 1999;51:3-22.

[63]. Vladmimir F. Kosov, Vladimir A., Lavrenov, Olga M. Larina and Viklor M. Zaichenko. Use of Two-stage pyrolysis for Bio-waste Recycling. Chem Eng Transact 2016;50.

[64]. S.T. Kumaravel, A. Murugesan and A. Kumaravel. Tyre proylsis oil as an alternative fuel for diesel engines: A review. Renew Sustain Energy Rev 2016;60:1678-1685.

[65]. Anke Krutof and Kelly Hawbodlt., Blends of Pyrolysis oil, Petroleum and other biobased fuels: A review. Renew Sustain Energy Rev 2016;59:406-419.

[66].Güray Yildizi, Frederick Ronsse, Ruben Van Duran and Wolter Prins. Challenges in the design and operation of Processess for catalytic fast pyrolysis of woody biomass. Renew Sustain Energy Rev 2016;57:1596-1610.

[67]. Manoj Tripathi, J.N. Sahu and P. Ganesan. Effect of process parameters on production of biochar from biomass waste through pyrolysis: A review. Renew Sustain Energy Rev 2016;55:467-481.

[68]. Sheikh Adil Edrisi and P.C. Abhilash. Exploring marginal and degraded lands for biomass and bioenergy production: An Indian scenario. Renew Sustain Energy Rev 2016;54:1537-1551.

[69]. Abdur Raheem, Mohammad Yusri Hassan and Rabia Shakoor. Bioenergy from anaerobic digestion in Pakistan: Potential, development and Prospects. Renew Sustain Energy Rev 2016;59:264-275. 
[70]. WT Tsai, MK Lee and YM Chang. Fast pyrolysis of rice husk: Product yields and compositions. Bioresource Technol 2007;98:22-28.

[71]. BB Uzun, AE Pütün and E Pütün. Fast pyrolysis of soybean cake: Product yields and compositions. Bioresource Techn 2006;97:569-576.

[72]. C Acıkgoz, O Onay and OM Kockar. Fast pyrolysis of linseed: Product yields and compositions. J Anal Appl Pyrolysis 2004;71:417-429.

[73]. Erik Dahlquist, Muhammad Naqvi, Eva Thorin, Jinyue Yan, Konstantinos Kyprianidis, Philip Hartwell, 2017. Experimental and numerical investigation of pellet and black liquor gasification for polygeneration plant. Accepted for publication in Applied Energy.

[74]. Muhammad Naqvi, Erik Dahlquist, Jinyue Yan, 2016. Complementing existing CHP plants using biomass for production of hydrogen and burning the residual gas in a CHP boiler. Biofuels. ISSN: 1759-7269. DOI:10.1080/17597269.2016.1153362.

[75]. Singh R, Shukla A. A review on methods of flue gas cleaning from combustion of biomass. Renew Sustain Energy Rev 2014;29:854-864

[76]. L.J.R. Nunes, J.C.O. Matias and J.P.S. Catalão. Biomass combustion systems: A review on the physical and chemical properties of the ashes. Renew Sustain Energy Rev 2015; 235242.

[77]. Muhammad Naqvi, Jinyue Yan, Erik Dahlquist, Salman Naqvi, 2017. Off-grid electricity generation using mixed biomass compost: A scenario-based study with sensitivity analysis. Applied Energy, article in press.

[78]. Asgher, M, Ahmad, Z, and Iqbal H. M. N. Alkali and enzymatic delignification of sugarcane bagasse to expose cellulose polymers for saccharification and bio-ethanol production. Indust Crops Prod 2013;44:488-495.

[79]. Zahid Anwar, Muhammad Gulfraz and Muhammad Irshad. Agro-industrial lignocellulosic biomass a key to unlock the future bio-energy: A brief review. J Radi Res Appl Sci 2014;7:163-173.

[80]. S.S. Amjad, M.Q. Bilal, M.S. Nazir and A. Hussain. Biogas: Renewable energy resource for Pakistan. Renew Sustain Energy Rev 2011;15:2833-2837.

[81]. Jones HB and Ogden EA. Biomass energy potential from livestock and poultry wastes in the Southern United States. Biomass 1984;6:25-35.

[82]. Tan $Z$ and Lagerkvist A. Phosphorus recovery from the biomass ash: A Review. Renew Sustain Energy Rev 2011;15:3588-602. 
[83]. Abdur Raheem, Mohammad Yusri Hassan and Rabia Shakoor. Bioenergy from anaerobic digestion in Pakistan: Potential, development and prospects. Renew Sustain Energy Rev 2016;59:264-275.

[84]. N.B. Singh, Ashwani Kumar and Sarita Rai; Potential production of bioenergy from biomass in an Indian perspective. Renew Sustain Energy Rev 2014;39:65-78

[85]. IEA: World Bioenergy Association (WBS). Global bioenergy statistics 2016. Available at: http: www.iea.org/stas/index.asp

[86]. Naim Rashid, Muhammad Saif Ur Rehman and Jong-In Han. Recycling and reuse of spent microalgal biomass for sustainable biofuels. Biochem Eng Journ 2013;75(15):101-107.

[87]. Omer Rauf, Shujie Wang, Peng Yuan and Junzhe Tan. An overview of energy status and development in Pakistan. Renew Sustain Energy Rev 2015;48:892-931.

[88]. P.K. Halder, N. Paul and M.R.A. Assessment of biomass energy resources and related technologies practice in Bangladesh. Renew Sustain Energy Rev 2014;39:444-460.

[89]. Bangladesh Sugarcane Research Institute. Ministry of Agriculture. Government of the People's Republic of Bangladesh, 〈http://www.bsri.gov.bd// [accessed January 2014].

[90]. Department of Agricultural Extension. Government of the People's Republic of Bangladesh. 〈http://www.dae.gov.bd/> [accessed January 2014].

[91]. Bangladesh Agriculture - products. 〈http://www.indexmundi.com/agriculture /?country=bd $\rangle$ [accessed January 2014].

[92]. Apex planet. 〈http://apexplanet.blogspot.com/2012/11/lakkatura-tea-estate-oldest-teagarden.html [accessed January 2014].

[93]. Cotton Development Board (CDB). Government of the People's Republic of Bangladesh. 〈http://www.cdb.gov.bd/> [accessed January 2014].

[94]. Ministry of Finance. Government of the People's Republic of Bangladesh. 〈http://www.mof.gov.bd/en/〉 [accessed January 2014].

[95]. A.S.N. Huda, S. Mekhilef and A. Ahsan. Biomass energy in Bangladesh: Current status and prospects. Renew Sustain Energy Rev 2013;504-517.

[96]. Junfeng L, Runqing H, Yanqin S, Jingli S, Bhattacharya SC and Abdul Salam P. Assessment of sustainable energy potential of non-plantation biomass resources in China. Biomass Bioenergy 2005;29(3):167-177. 
[97]. Mei Qu, Ying Lin, Can Liu, Shunbo Yao and Yang Cao. Farmers' perceptions of developing forest based bioenergy in China. Renew Sustain Energy Rev 2016;58:581-589.

[98]. Ravindranath NH, Somashekar HI, Nagaraja MS, Sudha P, Sangeetha G and Bhattacharya SC. Assessment of sustainable non-plantation biomass resources potential for energy in India. Biomass Bioenergy 2005;29 (3):178-190.

[99]. Moonmoon Hiloidhari, Dhiman Das and D.C. Baruah. Bioenergy potential from crop residue biomass in India. Renew Sustain Energy Rev 2014;32:504-512

[100]. Anil Kumar, Nitin Kumar, Prashant Baredar and Ashish Shukla. A review on biomass energy resources, potential, conversion. Renew Sustain Energy Rev 2015;530-539.

[101]. Bhattacharya SC, Abdul Salam P, Runqing H, Somashekar HI, Racelis DA and Rathnasiri PG. An assessment of the potential for non-plantation biomass resources in selected Asian countries for 2010. Biomass Bioenergy 2005;29(3):153-166.

[102]. Sajjakulnukit B, Yingyuad R, Maneekhao V, Pongnarintasut V and Bhattacharya SC, Abdul Salam P. Assessment of sustainable energy potential of non-plantation biomass resources in Thailand. Biomass Bioenergy 2005;29(3):214-224.

[103]. Elauria JC, Castro MLY, Elauria MM, Bhattacharya SC and Abdul Salam P. Assessment of sustainable energy potential of non-plantation biomass resources in the Philippines. Biomass Bioenergy 2005;29(3):191-198.

[104]. (PRES) Pakistan Renewable Energy Society. Promoting Green Energy for Better Tomorrow. available at: http://www.pres.org.pk/category/reaepakistan/bio-mass/

[105]. Umar K. Mirza, Nasir Ahmad and Tariq Majeed. An overview of biomass energy utilization in Pakistan. Renew Sustain Energy Rev 2008;12:1988-1996.

[106]. Peter Jacob Jørgensen. Biogas-Green energy. Faculty of Agricultural Sciences, Aarhus University $2^{\text {nd }}$ edition, Digisource Danmark A/S 2009.

[107]. S.C Bhattacharya and P Abdul Salam. Low greenhouse gas biomass options for cooking in the developing countries. Biomass Bioenergy 2002;22(4):305-317.

[108]. Akhter P. Country presentations: Promotion of Renewable Energy, Energy Efficiency and Greenhouses Gas Abatement (PREGA). In: Second Regional Training and Planning Workshop on Renew Energy 2004.

[109]. ADB. Islamic Republic of Pakistan: country environment analysis. Asian Development Bank 2008.

[110]. Ministry of Petroleum and Natural Resources, Government of Pakistan. 
[111]. NREL: National Renewable Energy Laboratory. Innovation for our energy future. August 2006. Available at: www.nrel.gov.

[112]. Greg Phal. Biodiesel: Grouping a new energy economy. $2^{\text {nd }}$ edition, Chelsea Green Publishing Company White River Junction, Vermont. August 2008.

[113]. Ma F and Hanna MA. Biodiesel production: A Review. Bioresources Technol 1999;70:1-15.

[114]. Pramanik K. Properties and use of Jatropha curcas oil and diesel fuel blends in compression ignition engine. Renew Energy 2003;28:239-248.

[115]. Schuchardta U, Serchelia R and Vargas RM. Transesterification of vegetable oils: A Review. J Braz Chem Soc 1998;9:199-210.

[116]. Freedman B, Pryde EH and Mounts TL. Variables affecting the yields of fatty esters from transesterified vegetable oils. JAOCS 1984;61:1638-1643.

[117]. Niven RK. Ethanol in gasoline: environmental impacts and sustainability review article. Renew Sustain Energy Rev 2005;9:535-555.

[118]. Mussatto SI, Dragone G, Guimarães PM, Silva JP, Carneiro LM and Roberto IC. Technological trends, global market, and challenges of bio-ethanol production. Biotechnol Adv 2010;28:817-30.

[119]. Demirbas A. Progress and recent trends in biofuels. Prog Energy Combust Sci 2007;33:1-18.

[120]. Sarkar N, Ghosh SK, Bannerjee S and Aikat K. Bioethanol production from agricultural wastes: An overview. Renew Energy 2012;37:19-27.

[121]. Mood SH, Golfeshan AH, Tabatabaei M, Jouzani GS, Najafi GH and Gholami M. Lignocellulosic biomass to bioethanol, a comprehensive review with a focus on pretreatment. Renew Sustain Energy Rev 2013;27:77-93.

[122].Ganguly A, Chatterjee PK and Dey A. Studies on ethanol production from water hyacinth: A Review. Renew Sustain Energy Rev 2012;16:966-972.

[123].Kosugi A, Kondo A, Ueda M, Murata Y, Vaithanomsat P and Thanapase W. Production of ethanol from cassava pulp via fermentation with a surface engineered yeast strain displaying glucoamylase. Renew Energy 2009;34:1354-1358.

[124]. Wei P, Cheng LH, Zhang L, Xu XH, Chen HL and Gao CJ. A review of membrane technology for bioethanol production. Renew Sustain Energy Rev 2014;30:388-400. 
[125]. Oscar JS and Carlos AC. Review: trends in biotechnological production of fuel ethanol from different feedstocks. Bioresources Technol 2008;99:5270-95.

[126]. Limayem A and Ricke SC. Lignocellulosic biomass for bioethanol production: current perspectives, potential issues and future prospects. Prog Energy Combust Sci 2012;38:449_ 67.

[127]. Government of Pakistan. Pakistan Economic Survey 2005-06. Islamabad, Pakistan: Economic Advisers Wing, Ministry of Finance 2006.

[128]. Umar K. Mirza, Nasir Ahmad and Tariq Majeed; An overview of biomass energy utilization in Pakistan. Renew Sustain Energy Rev 2008;12:1988-1996

[129]. Promotion of Renewable Energy, Energy Efficiency and Greenhouse Gas Abatement (PREGA)—Pakistan Country Report. Asian Development Bank 2004.

[130]. Pakistan integrated energy model: International Resources Group for Asian Development Bank and Ministry of Planning and Development Government of Pakistan 2010.

[131]. GOP. Pakistan Economic Survey 2009-10, June. Islamabad, Pakistan: Economic Advisers Wing, Ministry of Finance, Government of Pakistan 2010.

[132]. Larson ED and Kartha S. Expanding roles for modernized biomass energy. Energy Sustain Develop 2000;4:15-25.

[133].Omer Rauf, Shujie Wang, Peng Yuan and Junzhe Tan; An overview of energy status and development in Pakistan. Renew Sustain Energy Rev 2015;48:892-931

[134]. IEA: Energy Statistics 2012. Available at: http: www.iea.org/stas/index.asp.

[135]. Elizabeth Cushion, Adrian Whiteman and Gerhard Dieterle. Bioenergy Development: Issues and Impacts for Poverty and Natural Resource. (C) 2010 The World Bank. Washington DC 20433.

[136]. Ibrahim Dincer. Renewable energy and sustainable development: A crucial review. Renew Sustain Energy Rev 2000;4:157-175

[137]. O. Edenhofer, R. Pichs-Madruga, Y. Sokona, K. Seyboth, S. Kadner, T. Zwickel, P. Eickemeier, G. Hansen, S. Schlömer, Chris. von Stechow and P. Matschoss. Renewable Energy Sources and Climate Change Mitigation. Cambridge University Press 2012.

[138]. Daniela Cristina Momete. Analysis of Sustainable Biomass: A Three-Dimensional Approach. International Conference on Economic Engineering and Manufacturing Systems Braşov 2011. 
[139]. Patzek, T and Pimentel, D. Thermodynamics of Energy Production from Biomass. Critical Rev in Plant Sci 2005;24(5-6):327-364.

[140]. Irfan Afzal Mirza, Sana Ahmed and M. Shahid Khalil; Renewable Energy in Pakistan: Opportunities and challenges. A Sci J of Comsats - Science Vision 2011;(16-17).

[141] Mirza K, Ahmad N, Harijan K and Majeed T. Identifying and addressing barriers to renewable energy development in Pakistan. Renew Sustain Energy Rev 2009;13:927-31.

[142]. Asif A. Shah, S.M. Qureshi, Arabella Bhutto and Ambreen Shah. Sustainable development through renewable energy-The fundamental policy dilemmas of Pakistan Renew Sustain Energy Rev 2011;15:861-865.

[143]. Nidhal Abdulaziz and Mohammad Faisal Aziz. Prospects and Challenges of Renewable Energy in Pakistan 2010 IEEE International Energy Conference.

[144]. Syeda Shaima Meryem, Sheikh Saeed Ahmad and Neelam Aziz. Evaluation of biomass potential for renewable energy in Pakistan using LEAP model. Int J Emerg Trends in Eng and Develop 2013;3(1).

[145]. FBS, Pakistan statistical year book-2002: Federal Bureue of statistics (FBS), Government of Pakistan March 2002.

[146]. Hassan M.U, 2002 Biogas Technology to light up villages in Pakistan: Karachi Dawn science-dot-com magazine 2002;(14):6-7.

[147]. APEC (Asia- Pacific Economic cooperation) Energy Outlook for Asia and the Pacific. (C) 2013 Asian Development Bank.

[148]. Ashraf CM, Raza R and Hayat SA. Renewable energy technologies in Pakistan: Prospects and challenges. Renew Sustain Energy Rev 2009;13.6:1657-1662.

[149]. S. Ahmed, A. Mahmood, A.Hasan, G.Ahmad, S. Sidhu and M. Fasih Uddin Butt. A comparative review of China, India and Pakistan renewable energy sectors and sharing opportunities. Renew Sustain Energy Rev 2016;57:216-225.

[150]. Zuberi MJS, Hasany SZ, Tariq MA and Farrioglu M. Assessment of biomass energy resources potential in Pakistan for power generation. IEEE fourth international conference on power engineering, energy and electrical drives (POWERENG). Istanbul 2013;1301-1306.

[151]. Muhammad Naqvi, Jinyue Yan, Erik Dahlquist. Synthetic natural gas (SNG) production at pulp mills from a circulating fluidized bed black liquor gasification process with direct causticization. 23rd International Conference on Efficiency, Cost, Optimization, Simulation, and Environmental Impact of Energy Systems, ECOS 2010. Lausanne, Switzerland.Volume 2: Pages 83-91. 
[152]. Dr. Ehsan Ali and Ms. Nafeesa Irshad. Center for Advanced Studies in Energy at NUST (CAS-EN). Final Report : Survey on the Availability of Biomass in Punjab Pakistan Resource Mapping Study by IFC-World Bank Group 2015.

[153]. Chaudhry MA, Raza R and Hayat SA. Renewable energy technologies in Pakistan: prospects and challenges. Renew Sustain Energy Rev 2009;13:1657-62. 
Figure 1

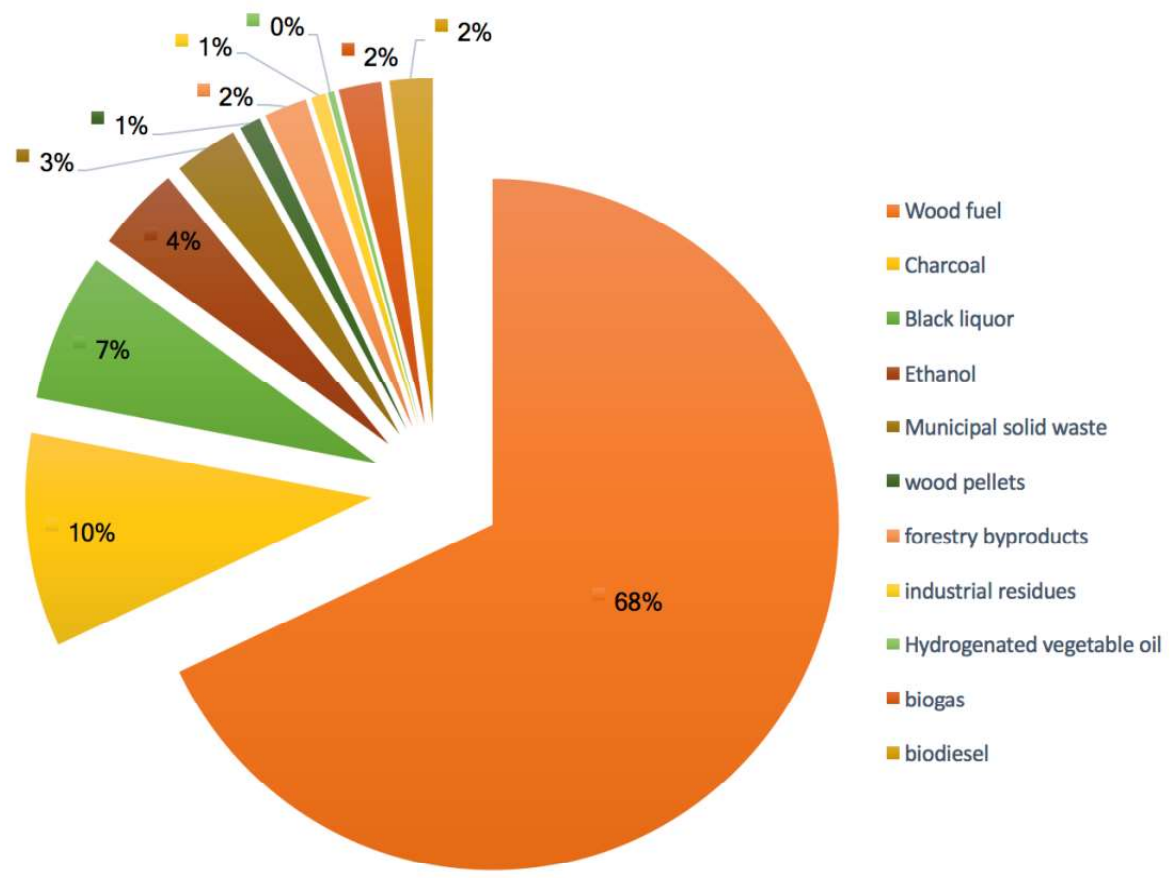

Figure 1: Global biomass distribution as primary resource [7] 
Figure 2

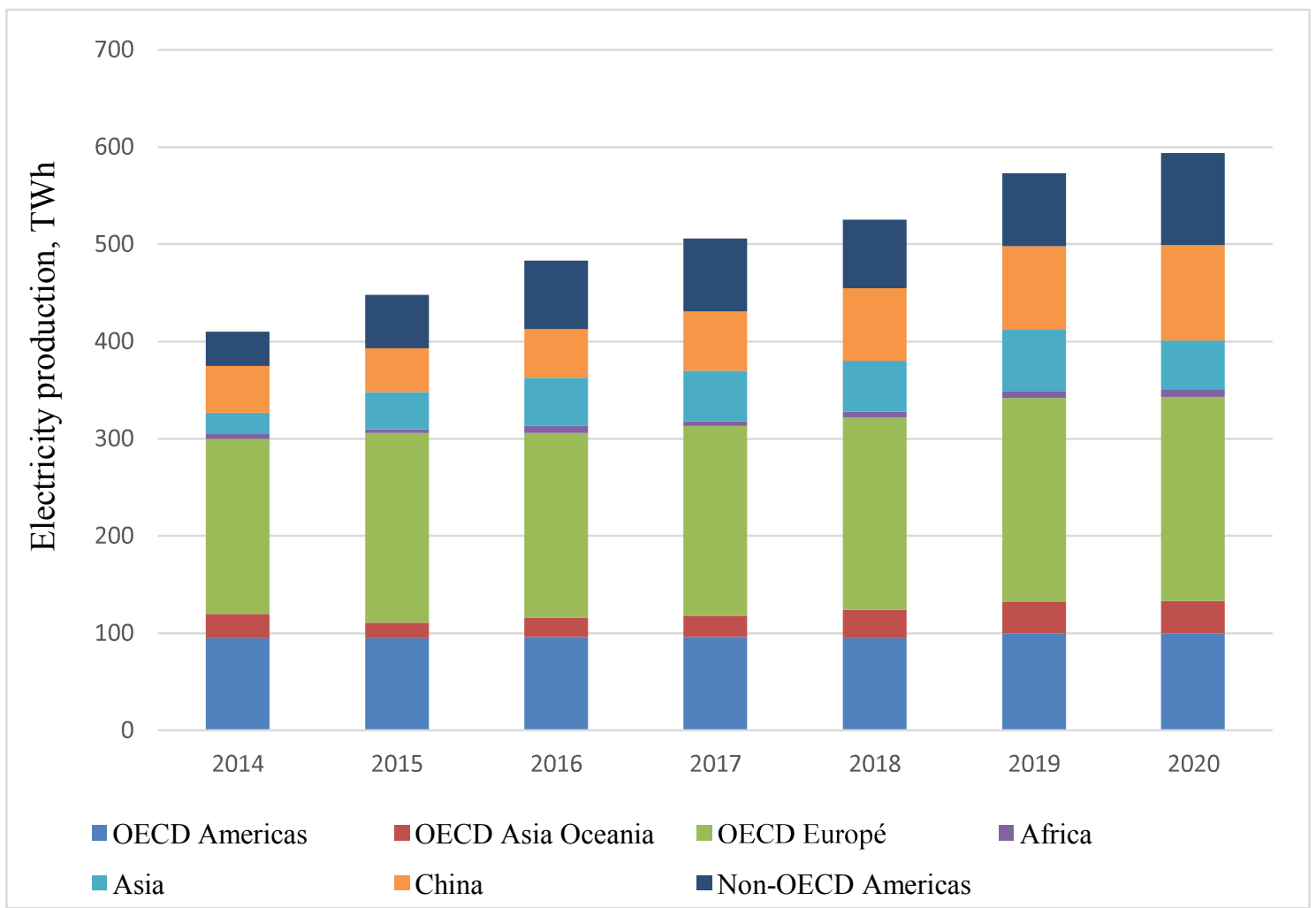

Figure 2: Regional biomass-based electricity production from 2014 and forecast till 2020 [9] 
Figure 3

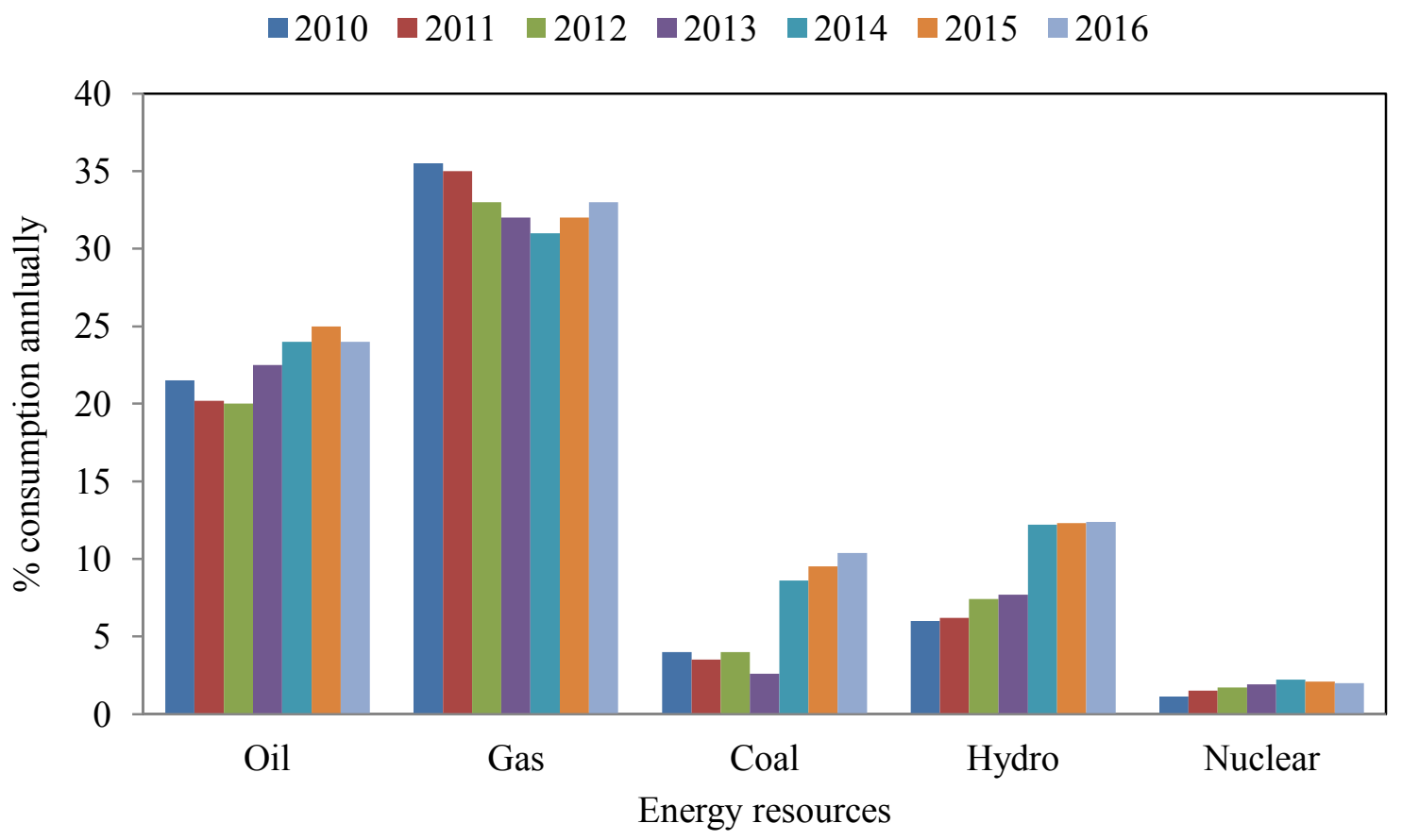

Figure 3: Energy consumption from various resources in Pakistan from 2010 to 2016 [14] 
Figure 4

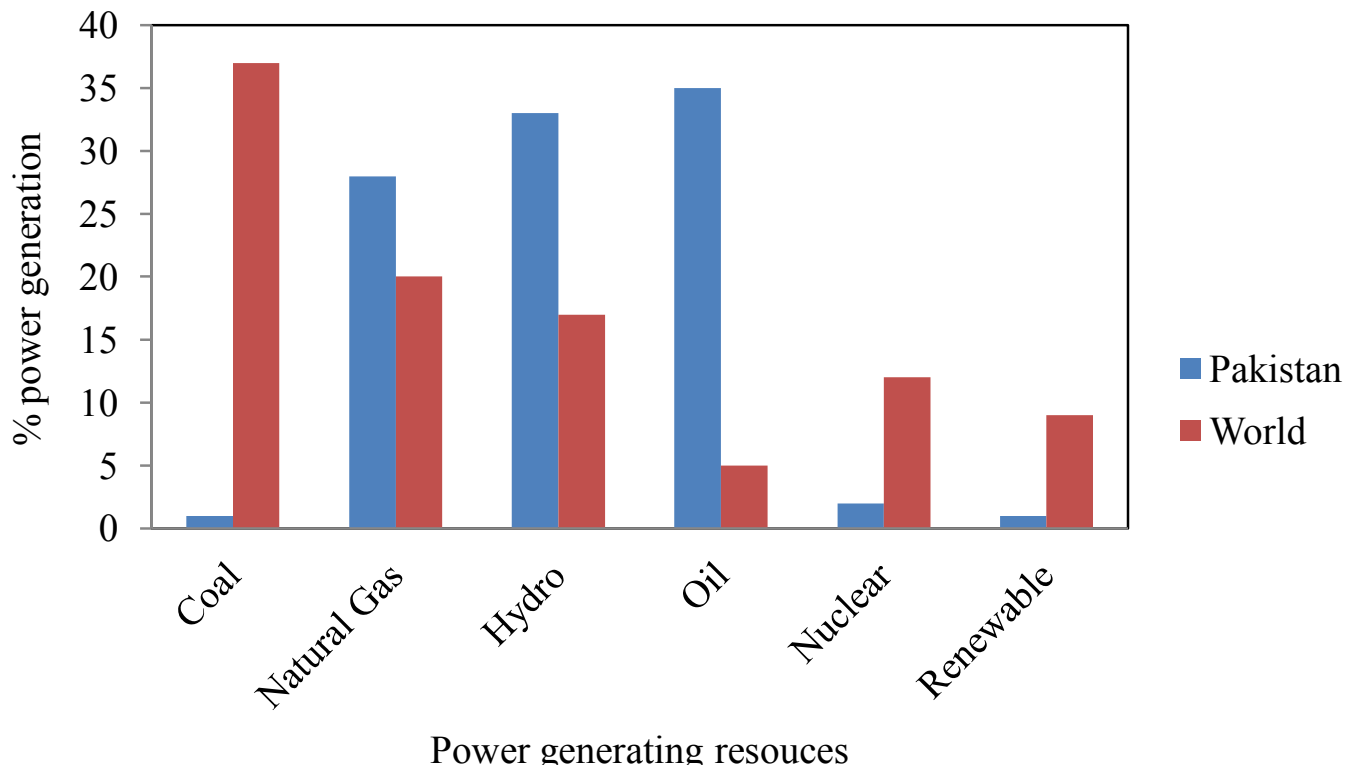

Figure 4: Global and Pakistan fuel mix for power generation of year 2015 [37] 
Figure 5
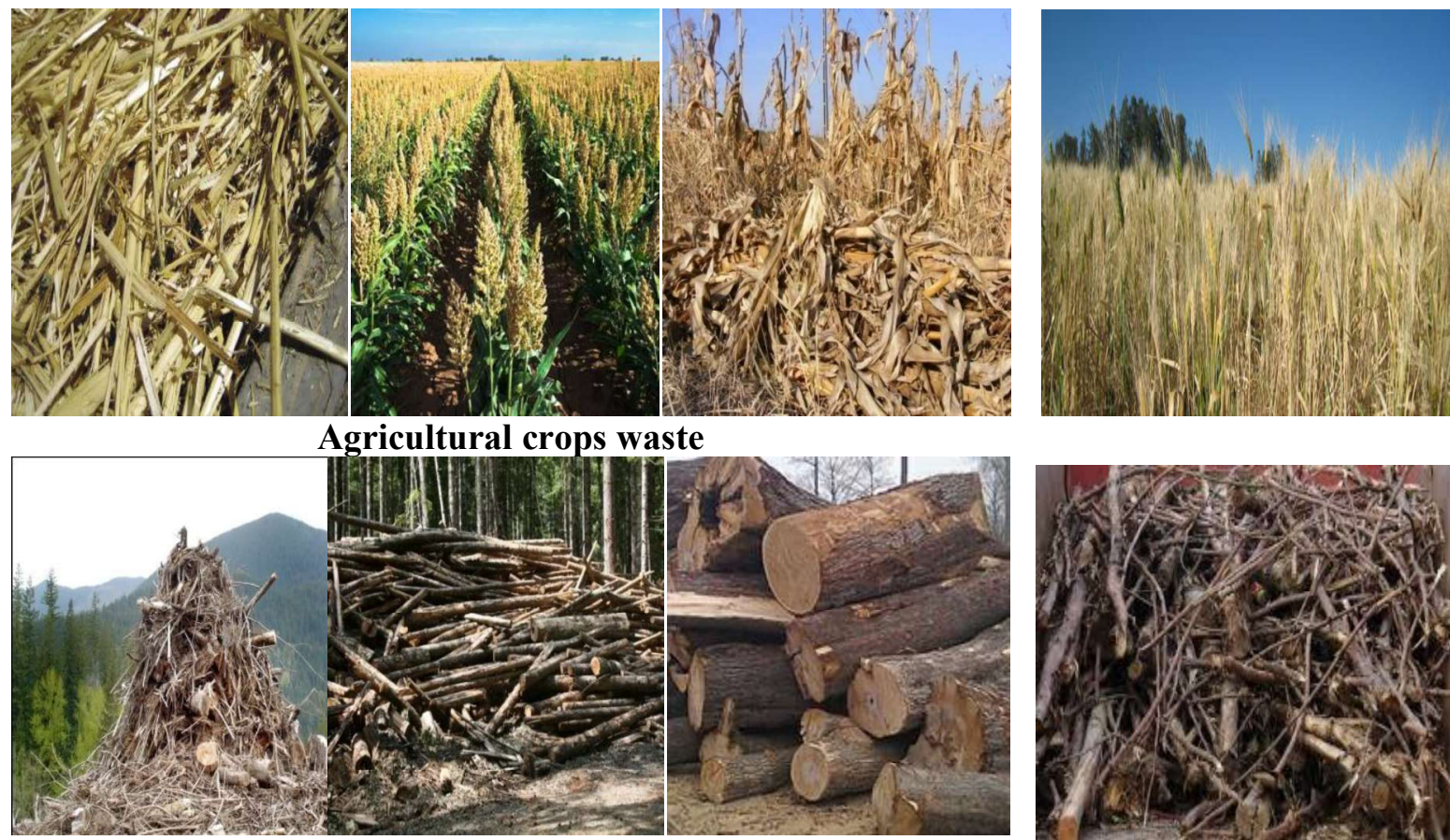

\section{Forest wood Residue}
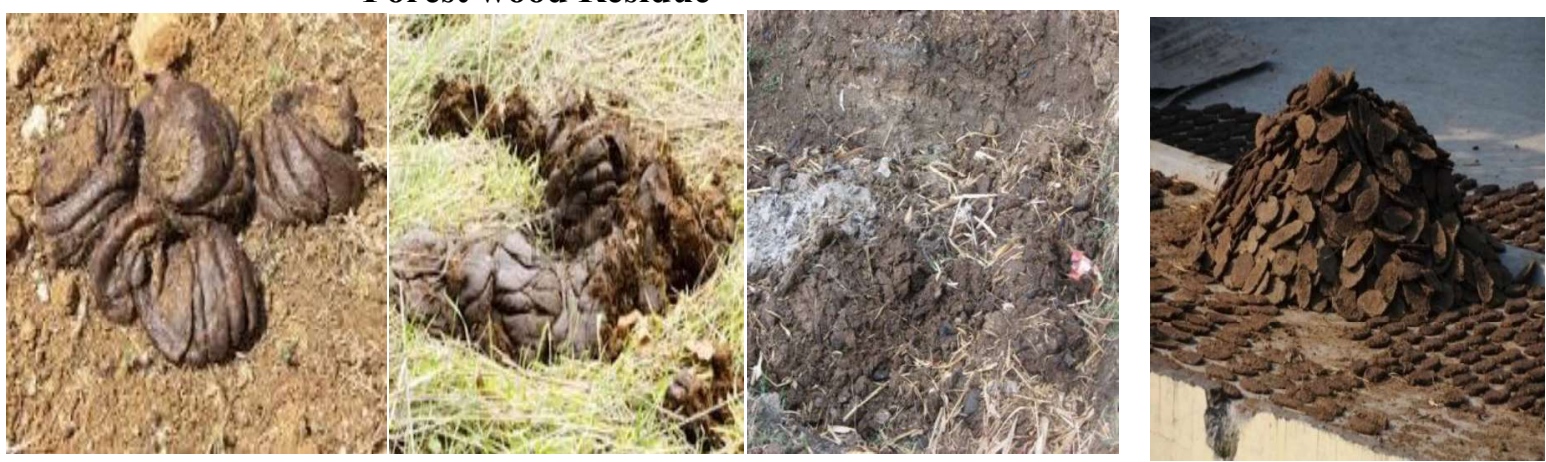

Animal Waste
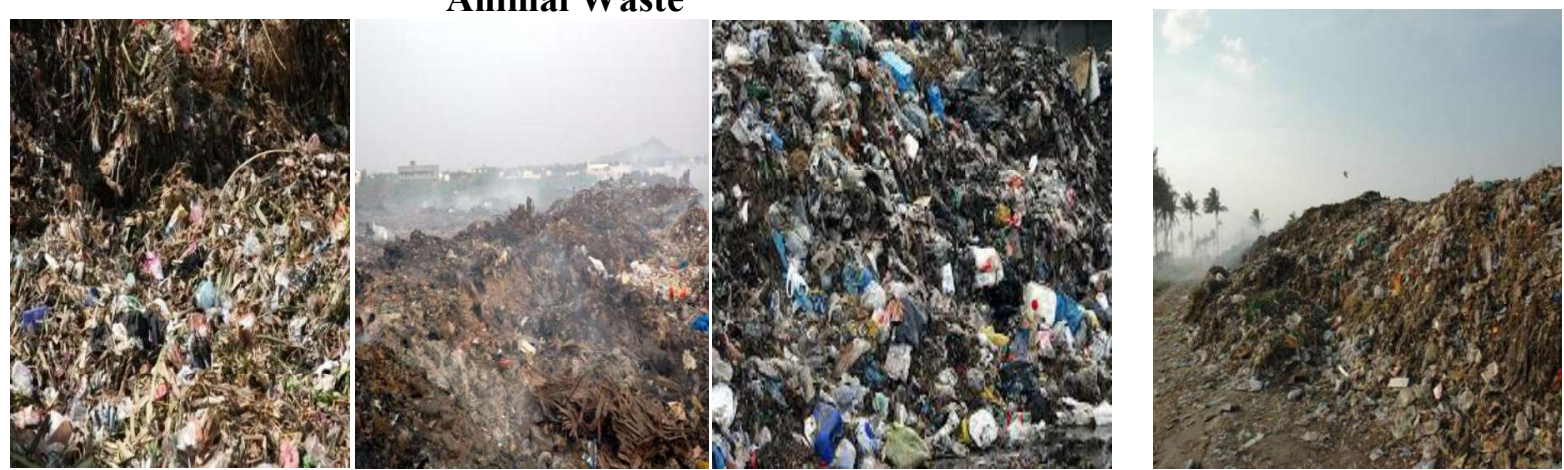

Municipal Solid Waste

Figure 5: Available resources of biomass in Pakistan. 
Figure 6

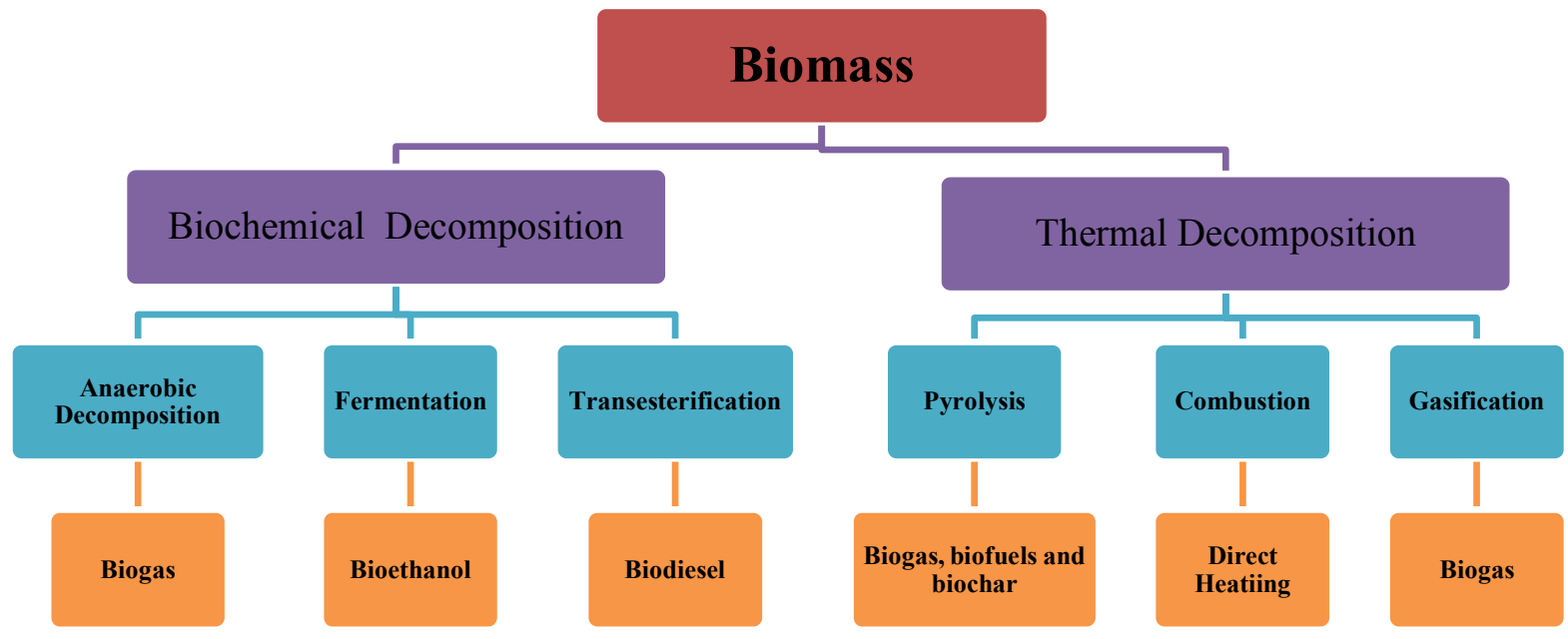

Figure 6: Steps involved in conversion of bioenergy from biomass [34-36] 
Table 1: Various biomass resources with their utilization, conversion and potential use as bioenergy product.

\begin{tabular}{|c|c|c|c|c|}
\hline $\begin{array}{l}\text { Biomass } \\
\text { resource }\end{array}$ & Current utilization & $\begin{array}{l}\text { Potential } \\
\text { conversion } \\
\text { technology }\end{array}$ & $\begin{array}{l}\text { Potential end use as } \\
\text { an energy product }\end{array}$ & Reference \\
\hline Wheat straw & $\begin{array}{l}\text { Domestic heating, paper } \\
\text { products etc. }\end{array}$ & Gasification & $\begin{array}{lr}\text { SNG, } & \text { off-grid } \\
\text { electricity } & \text { generation, } \\
\text { etc. } & \end{array}$ & 49,50 \\
\hline Rice husk & $\begin{array}{l}\text { Fuel, Making of activated } \\
\text { carbon, Pet food fiber etc. }\end{array}$ & $\begin{array}{l}\text { Combustion } \\
\text { and } \\
\text { Gasification. }\end{array}$ & $\begin{array}{l}\text { Off grid energy } \\
\text { generation, substitute } \\
\text { house-hold energy. }\end{array}$ & 51,50 \\
\hline Bagasse & $\begin{array}{l}\text { Bioethanol production, } \\
\text { Fuel production etc. }\end{array}$ & $\begin{array}{l}\text { Hydrolysis, } \\
\text { Fermentation. }\end{array}$ & $\begin{array}{l}\text { Renewable Motor } \\
\text { Fuel. }\end{array}$ & 49 \\
\hline $\begin{array}{l}\text { Poultry/cow } \\
\text { manure }\end{array}$ & $\begin{array}{l}\text { Fertilizer, Biogas } \\
\text { production etc. }\end{array}$ & $\begin{array}{l}\text { Fermentation, } \\
\text { Composting. }\end{array}$ & $\begin{array}{l}\text { Bio-Gas, Methane and } \\
\text { house-hold fuel. }\end{array}$ & 49,50 \\
\hline $\begin{array}{l}\text { Forestry } \\
\text { residues \& } \\
\text { wood }\end{array}$ & $\begin{array}{l}\text { Biomass production, } \\
\text { Fertilizer, Fuel etc }\end{array}$ & $\begin{array}{l}\text { Saw-milling, } \\
\text { Grinding etc }\end{array}$ & Fuel wood. & 52,53 \\
\hline $\begin{array}{l}\text { Municipal } \\
\text { solid waste }\end{array}$ & $\begin{array}{l}\text { Bottom ash production, } \\
\text { strengthening concrete etc }\end{array}$ & $\begin{array}{l}\text { Combustion, } \\
\text { Sieving, } \\
\text { Pyrolysis. }\end{array}$ & $\begin{array}{l}\text { Production of } \\
\text { methanol ethanol } \\
\text { methane and syn gas }\end{array}$ & 54,50 \\
\hline
\end{tabular}


Table 1.2: Total primary energy supply (TPES) of biomass in different countries 2016 [85]

\begin{tabular}{lllllll}
\hline No. & Country & $\begin{array}{l}\text { TPES } \\
\text { biomass }(\text { EJ) }\end{array}$ & $\begin{array}{l}\text { TPES } \\
\text { capita }(\mathbf{G J})\end{array}$ & $\begin{array}{l}\text { per } \\
\text { GPES } \\
\text { GDP }(\mathbf{M J} / \mathbf{s})\end{array}$ & $\begin{array}{l}\text { Share of biomass in } \\
\text { PES }(\%)\end{array}$ \\
\hline 1. & India & 8.41 & 6.79 & 5.88 & 23.50 \\
2. & USA & 4.12 & 12.40 & 0.28 & 35.51 \\
3. & Brazil & 4.07 & 16.89 & 2.99 & 28.30 \\
4. & Indonesia & 2.39 & 9.23 & 5.33 & 25.44 \\
5. & Pakistan & 1.27 & 6.97 & 8.92 & 5.58 \\
6. & Germany & 2.37 & 16.55 & 4.38 & 25.57 \\
7. & Thailand & 0.94 & 14.88 & 4.41 & 18.42 \\
8. & China & 9.39 & 6.81 & 5.05 & 17.99 \\
9. & World & 57.7 & 8.27 & 1.10 & 10.20 \\
\hline
\end{tabular}


Table 3: Comparison of biomass production and its energy potential in Asian countries

\begin{tabular}{|c|c|c|c|c|c|}
\hline No. & Countries & $\begin{array}{l}\text { Biomass Production } \\
\text { Mt } \mathbf{Y r}^{-1}\end{array}$ & $\begin{array}{l}\text { Biomass } \\
\text { potential (PJ) }\end{array}$ & energy & References \\
\hline 1 & Bangladesh & $54-61$ & 1344.99 & & 94,95 \\
\hline 2 & China & $182.5-210.5$ & 8899.8 & & 96,97 \\
\hline 3 & India & $62-310$ & 8764 & & $98,99,100$ \\
\hline 4 & Sri Lanka & $2.0-9.9$ & 141.8 & & 101 \\
\hline 5 & Thailand & $11.6-106.6$ & 821.4 & & 102 \\
\hline 6 & Philippine & $3.7-20.4$ & 968.7 & & 103 \\
\hline 7 & Pakistan & $0.23-0.31$ & 0.806 & & 104,105 \\
\hline
\end{tabular}


Table 4: Largest countries using bioenergy on industrial sector [134]

\begin{tabular}{|c|c|c|c|c|}
\hline No. & Country & $\begin{array}{ll}\text { *Primary } & \text { solid } \\
\text { biomass (PJ) } & \end{array}$ & $\begin{array}{l}\text { Industrial Use } \\
\text { Biomass (PJ) }\end{array}$ & Global Share \\
\hline 1 & Brazil & 1317 & 1317 & 18 \\
\hline 2 & India & 1195 & 1195 & 16 \\
\hline 3 & United States & 1063 & 1171 & 16 \\
\hline 4 & Nigeria & 379 & 379 & 5 \\
\hline 5 & Canada & 287 & 287 & 4 \\
\hline 6 & Thailand & 283 & 283 & 4 \\
\hline 7 & Indonesia & 272 & 272 & 4 \\
\hline 8 & Congo & 185 & 185 & 3 \\
\hline 9 & Swedan & 169 & 169 & 2 \\
\hline 10 & Pakistan & 135 & 135 & 2 \\
\hline 11 & Finland & 111 & 112 & 2 \\
\hline 12 & Australia & 105 & 105 & 1 \\
\hline 13 & $\begin{array}{l}\text { Other } \\
\text { countries }\end{array}$ & 1752 & 1790 & 23 \\
\hline 14 & World & 7220 & 7366 & 100 \\
\hline
\end{tabular}

*Primary solid mass $=$ MSW, Agricultural residues especially bagasse 


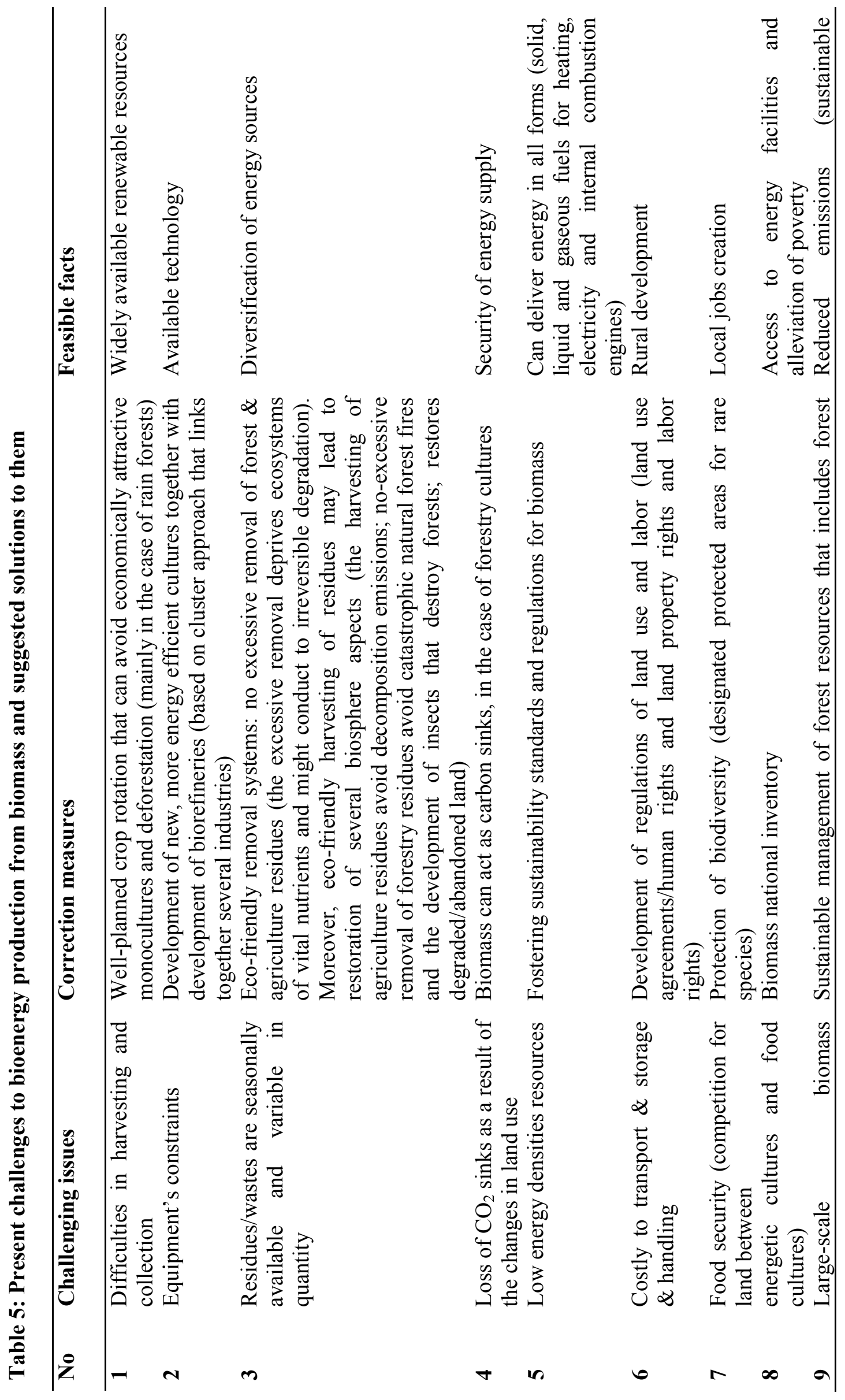




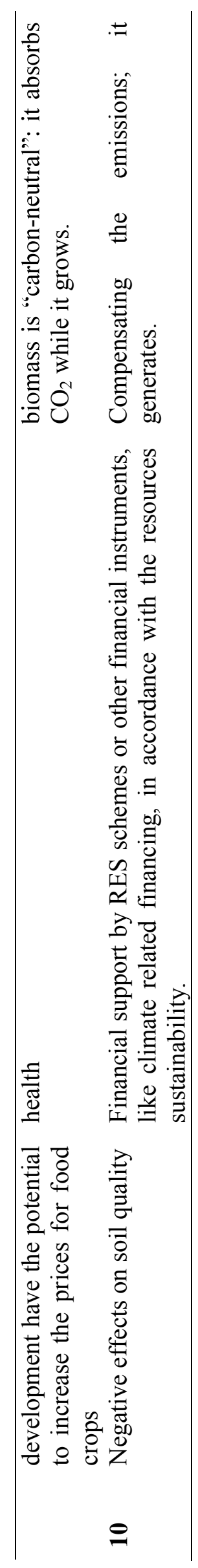


Table 6: Gradual increasing inclination of non woody biomass and animal growth up to 2030 [144]

\begin{tabular}{|c|c|c|c|c|c|}
\hline Category & No & Type of Biomass & 2009 & 2012 & 2030 \\
\hline & 1. & Bajra & 470 & 588.8 & 2275.6 \\
\hline & 2. & Maize & 296 & 370.8 & 1433.1 \\
\hline million & 3. & Barley & 82 & 102.7 & 397 \\
\hline tonnes & 4. & Dry Chili & 18.8 & 23.5 & 90.9 \\
\hline & & Total & 866.8 & 1085.8 & 4196.6 \\
\hline & 5. & Rice & 6.9 & 7.5 & 12.8 \\
\hline \multirow{4}{*}{ Crops in trillion } & 6. & Cotton & 3 & 3.3 & 5.5 \\
\hline & 7. & Wheat & 23.9 & 26.9 & 51.4 \\
\hline & 8. & Baggasse & 49.4 & 53.1 & 82.6 \\
\hline & & Total & 83.1 & 90.6 & 152.2 \\
\hline \multirow{5}{*}{ Animal Live Stock in millions } & 9. & Buffalo & 36.9 & 46.5 & 185.7 \\
\hline & 10. & Cattle & 34.3 & 43.2 & 172.7 \\
\hline & 11. & Sheep & 27.8 & 31 & 59.6 \\
\hline & 12 & Camel & 1 & 1.1 & 2.1 \\
\hline & & Total & 159.9 & 188.6 & 548.6 \\
\hline
\end{tabular}


Table 7: Different organization and universities working on development of Biomass Bioenergy [153]

\begin{tabular}{|c|c|c|c|}
\hline No. & Govt. Organizations & Private Organization & Universities \\
\hline 1. & $\begin{array}{l}\text { Directorate of New and Renewable } \\
\text { Energy Ministry of Petroleum and } \\
\text { Natural Resources }\end{array}$ & $\begin{array}{l}\text { Renewable and alternative } \\
\text { energy association of } \\
\text { Pakistan (REAP) }\end{array}$ & $\begin{array}{l}\text { NED university of engineering and } \\
\text { technology Karachi. }\end{array}$ \\
\hline 2. & $\begin{array}{l}\text { Alternative Energy Development } \\
\text { Board, Ministry of Water and } \\
\text { Power. Government of Pakistan } \\
\text { (AEDB) }\end{array}$ & $\begin{array}{l}\text { Engineering } \\
\text { Company }\end{array}$ & $\begin{array}{l}\text { (NUST) National University of } \\
\text { Science Technology Rawalpindi }\end{array}$ \\
\hline 3. & $\begin{array}{l}\text { National Commission for } \\
\text { Alternative Energy }\end{array}$ & M.G. Engineering Associates & $\begin{array}{l}\text { (UET) University of Engineering } \\
\text { and Technology Lahore }\end{array}$ \\
\hline 4. & $\begin{array}{l}\text { Solar Energy Research Center } \\
\text { (PCSIR) }\end{array}$ & $\begin{array}{l}\text { Trans Mark International } \\
\text { Pvt. Ltd. }\end{array}$ & $\begin{array}{l}\text { (BZU) Bahaudin } \quad \text { Zakirya } \\
\text { University Multan }\end{array}$ \\
\hline 5. & $\begin{array}{l}\text { Pakistan Council for Renewable } \\
\text { Energy technologies (PCRET) }\end{array}$ & $\begin{array}{l}\text { East End Engineers (Pvt.) } \\
\text { Ltd. }\end{array}$ & $\begin{array}{l}\text { (SZABIST) Shaheed Zulfikar Ali } \\
\text { Bhutto Institute of Science and } \\
\text { Technology }\end{array}$ \\
\hline 6. & - & Tecnasia International & $\begin{array}{l}\text { COMSAT Institute of Information } \\
\text { and Technology (CIIT) }\end{array}$ \\
\hline 7. & - & Sky Green Engineering & $\begin{array}{l}\text { (AUF) Agriculture University of } \\
\text { Faisalabad }\end{array}$ \\
\hline 8. & - & EngroTech & University of Baluchistan Quetta. \\
\hline
\end{tabular}

